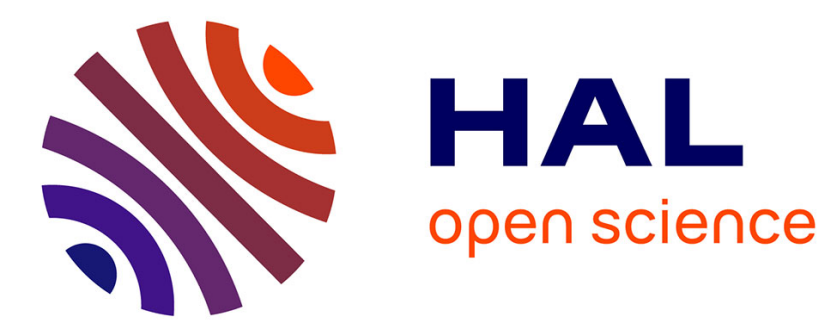

\title{
High-solids anaerobic digestion model for homogenized reactors
}

Vicente Pastor Poquet, Stefano Papirio, Jean-Philippe Steyer, Eric Trably, Renaud Escudié, Giovanni Esposito

\section{To cite this version:}

Vicente Pastor Poquet, Stefano Papirio, Jean-Philippe Steyer, Eric Trably, Renaud Escudié, et al.. High-solids anaerobic digestion model for homogenized reactors. Water Research, 2018, 142, pp.501511. 10.1016/j.watres.2018.06.016 . hal-02625164

\section{HAL Id: hal-02625164 \\ https://hal.inrae.fr/hal-02625164}

Submitted on 2 Jun 2021

HAL is a multi-disciplinary open access archive for the deposit and dissemination of scientific research documents, whether they are published or not. The documents may come from teaching and research institutions in France or abroad, or from public or private research centers.
L'archive ouverte pluridisciplinaire HAL, est destinée au dépôt et à la diffusion de documents scientifiques de niveau recherche, publiés ou non, émanant des établissements d'enseignement et de recherche français ou étrangers, des laboratoires publics ou privés.

\section{(ㅇ)(1) $\$$}

Distributed under a Creative Commons Attribution - NonCommercial - NoDerivatives| 4.0 


\section{Accepted Manuscript}

High-solids anaerobic digestion model for homogenized reactors

Vicente Pastor-Poquet, Stefano Papirio, Jean-Philippe Steyer, Eric Trably, Renaud Escudié, Giovanni Esposito

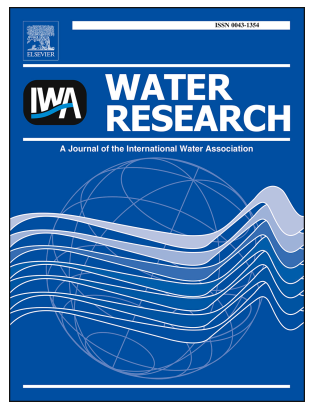

PII:

S0043-1354(18)30460-3

DOI:

10.1016/j.watres.2018.06.016

Reference: WR 13843

To appear in: Water Research

Received Date: 19 March 2018

Revised Date: 22 May 2018

Accepted Date: 7 June 2018

Please cite this article as: Pastor-Poquet, V., Papirio, S., Steyer, J.-P., Trably, E., Escudié, R., Esposito, G., High-solids anaerobic digestion model for homogenized reactors, Water Research (2018), doi: 10.1016/j.watres.2018.06.016.

This is a PDF file of an unedited manuscript that has been accepted for publication. As a service to our customers we are providing this early version of the manuscript. The manuscript will undergo copyediting, typesetting, and review of the resulting proof before it is published in its final form. Please note that during the production process errors may be discovered which could affect the content, and all legal disclaimers that apply to the journal pertain. 


\section{Graphical Abstract}

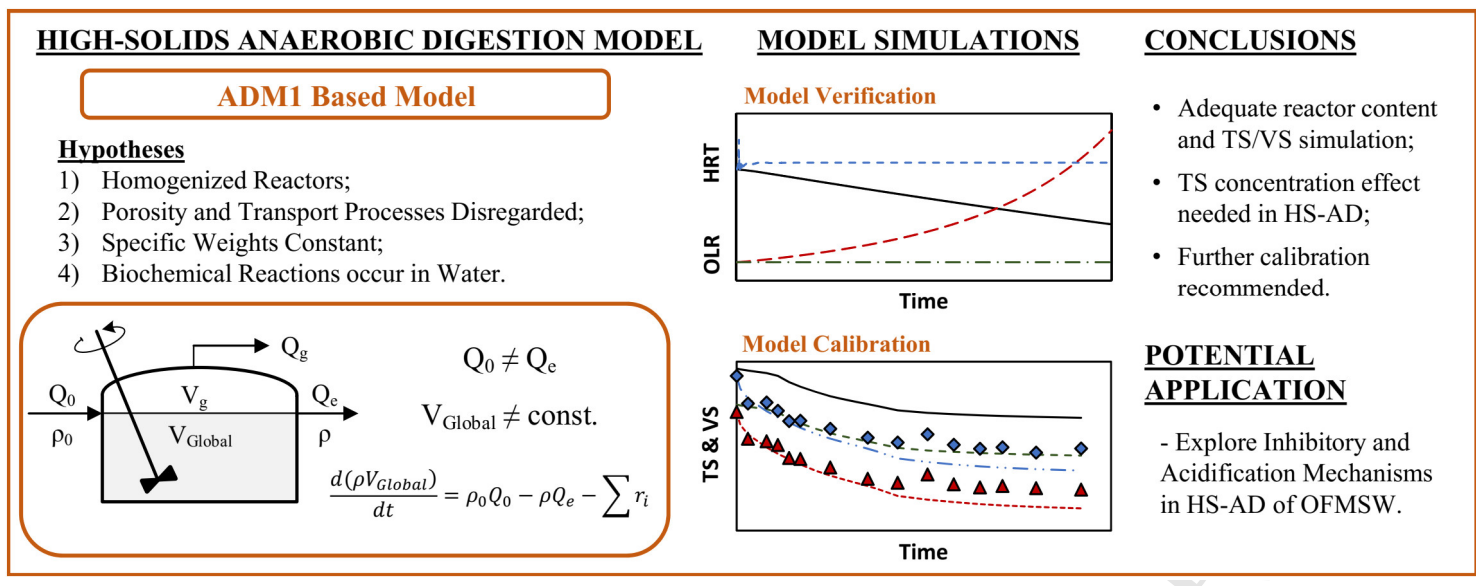


1 High-Solids Anaerobic Digestion Model for Homogenized Reactors

2

3 Vicente Pastor-Poquet ${ }^{\mathrm{a}, \mathrm{b},{ }^{*},}$, Stefano Papirio ${ }^{\mathrm{c}}$, Jean-Philippe Steyer ${ }^{\mathrm{b}}$, Eric Trably ${ }^{\mathrm{b}}$,

4 Renaud Escudié $^{\mathrm{b}}$, and Giovanni Esposito ${ }^{\mathrm{a}}$

5

$6 \quad{ }^{a}$ Department of Civil and Mechanical Engineering, University of Cassino and Southern

7 Lazio, via Di Biasio 43, 03043 Cassino (FR), Italy

$8 \quad *$ Corresponding author. E-mail: vicente.pastor.poquet@gmail.com

$9{ }^{\mathrm{b}}$ LBE, Univ Montpellier, INRA, 102 avenue des Etangs, 11100, Narbonne, France

$10{ }^{\mathrm{c}}$ Department of Civil, Architectural and Environmental Engineering, University of

11 Napoli Federico II, via Claudio 21, 80125 Napoli, Italy

12 


\section{ABSTRACT}

14 During high-solids anaerobic digestion (HS-AD) of the organic fraction of municipal

15 solid waste (OFMSW), an important total solid (TS) removal occurs, leading to the

16 modification of the reactor content mass/volume, in contrast to 'wet' anaerobic

17 digestion (AD). Therefore, HS-AD mathematical simulations need to be approached

18 differently than 'wet' AD simulations. This study aimed to develop a modelling tool

19 based on the anaerobic digestion model 1 (ADM1) capable of simulating the TS and the

20 reactor mass/volume dynamics in the HS-AD of OFMSW. Four hypotheses were used,

21 including the effects of apparent concentrations at high TS. The model simulated

22 adequately HS-AD of OFMSW in batch and continuous mode, particularly the

23 evolution of TS, reactor mass, ammonia and volatile fatty acids. By adequately

24 simulating the reactor content mass/volume and the TS, this model might bring further

25 insight about potentially inhibitory mechanisms (i.e. $\mathrm{NH}_{3}$ buildup and/or acidification)

26 occurring in HS-AD of OFMSW.

27

28 Keywords: High-Solids Anaerobic Digestion; ADM1; Reactor Mass Simulation; Total

29 Solids; Apparent Concentrations. 
31

32

\section{INTRODUCTION}

Anaerobic digestion (AD) is a biochemical treatment technology for organic waste valorization yielding a high-methane-content biogas and a partially stabilized organic material with potential applications as soil amendment (Mata-Alvarez 2003). Highsolids anaerobic digestion (HS-AD) is a particular case of AD operated at a total solid (TS) content $\geq 10 \%$, in contrast to 'wet' AD applications (i.e. TS $<10 \%$ ) (AbbassiGuendouz et al. 2012). Thus, HS-AD has the advantage of minimizing the reactor volume, as well as the need for water addition. On the other hand, HS-AD is normally associated with an important reduction of the total (TS) and volatile (VS) solid content, during the biological degradation of the organic matter. For example, HS-AD of the organic fraction of municipal solid waste (OFMSW) might lead to a TS removal of 30 $80 \%$ (Cecchi et al. 2002, Mata-Alvarez 2003, Pavan et al. 2000). However, some drawbacks limit the applicability of HS-AD as, for example, the reduced kinetics expected as a consequence of the hampered mass transfer, and the high risk of acidification due to organic overloading (Benbelkacem et al. 2015, De Baere 2000). Among the solid wastes used in HS-AD, the OFMSW is particularly suited for anaerobic treatment due to its elevated TS content (i.e. 25 - $30 \%$ ), biodegradation potential and possibility to recover nutrients (i.e. nitrogen and phosphorous) from its composition (De Baere and Mattheeuws 2013, Mata-Alvarez 2003). However, HS-AD of OFMSW is normally associated with a high risk of inhibition due to the high protein content, leading to free ammonia nitrogen $\left(\mathrm{NH}_{3}\right)$, as one of the most important inhibitors (Chen et al. 2008, Kayhanian 1999, Rajagopal et al. 2013). Understanding the biochemical and physicochemical dynamics in HS-AD is crucial to ease the design and operation of HS-AD reactors, minimizing the risk of 
acidification/inhibition. Particularly important is the knowledge about the interactions between the main four phases - microorganisms, solids, liquids and gases - in HS-AD, since it might allow to increase the waste treatment capabilities and methane yield (Mata-Alvarez 2003, Vavilin et al. 2004, Xu et al. 2015). In this line, an adapted mathematical model is required for the operational analysis and technology development of HS-AD, as some of the main applications for 'wet' AD of the anaerobic digestion model No.1 (ADM1) (Batstone 2006, Batstone et al. 2002, Batstone et al. 2015, Xu et al. 2015).

ADM1 is a structured model gathering together the main biochemical and physicochemical processes of AD (Batstone et al. 2002, Batstone et al. 2015).

Biochemical processes include the disintegration, hydrolysis, acidogenesis, acetogenesis and methanogenesis of complex substrates composed of carbohydrates, proteins and lipids in chemical oxygen demand (COD) units. Physicochemical processes include the gas transfer and the equilibrium of the ionic species of the main inorganic compounds in $\mathrm{AD}$ (i.e. $\mathrm{CO}_{2}$ and $\mathrm{NH}_{3}$ ). However, the CSTR implementation of ADM1 was primarily conceived for 'wet' AD applications (i.e. TS $\ll 10 \%$ ), while a more complex hydraulic and particulate component modeling is required for HS-AD (Batstone et al. 2002, Batstone et al. 2015, Xu et al. 2015). Thus, modelling HS-AD might be particularly challenging due to the intrinsic complexity of the process (Batstone et al. 2015, Mata-Alvarez et al. 2000, Vavilin et al. 2004, Xu et al. 2015). For example, the (semi-)solid matrix might define the soluble/gaseous transport processes, as well as the capabilities of anaerobic biomass to access the substrates (Bollon et al. 2013, Vavilin and Angelidaki 2005). 
78 The mass balance modification, regarding the continuously stirred tank reactor (CSTR)

79 implementation of ADM1 (Batstone et al. 2002), is required to account for the reactor

80 content mass $\left(\mathrm{M}_{\text {Global }}\right)$ removal and the specific weight $\left(\rho_{\text {Global }}\right)$ dynamics in HS-AD

81 (Batstone et al. 2015, Kayhanian and Hardy 1994, Richards et al. 1991, Vavilin et al.

82 2004). Noteworthy, the reactor content volume $\left(V_{\text {Global }}\right)$ might describe important

83 fluctuations during HS-AD, depending mainly on the substrate TS and biodegradability,

84 in contrast to 'wet' AD. Furthermore, a given degree of gaseous porosity $(\epsilon)$ might be present in the HS-AD matrix, particularly at TS contents $\geq 25 \%$ (Batstone et al. 2015, Benbelkacem et al. 2013, Bollon et al. 2013, Vavilin et al. 2003). ADM1 was originally expressed in volumetric units (i.e. $\mathrm{kg} \mathrm{COD} / \mathrm{m}^{3}$ ). Meanwhile, the most common measurements in HS-AD are normally expressed in mass units (i.e. $\mathrm{kg} \mathrm{COD} / \mathrm{kg}$ ), since accounting for the specific weight of (semi-)solid samples - but also the specific weight dynamics in HS-AD - involves the complexity of the analytical techniques example, the specific weight of a (semi-)solid sample can be approximated by the use of a water pycnometer, where the sample must be appropriately pretreated (i.e. dried/ground), the distilled water fully degassed and analyses performed under temperature-controlled conditions (ASTM 2002). With all the above, HS-AD simulations need to be approached differently than in 'wet' $\mathrm{AD}$, where $\rho_{\text {Global }}$ and $\mathrm{V}_{\text {Global }}$ 97 are normally assumed constant, as summarized in Figure 1.

98 This study aimed at developing a mathematical tool based on the ADM1 biochemical

99 framework, capable of simulating the solids and reactor content mass/volume dynamics

100 in HS-AD of OFMSW, including the interrelationship between TS (and VS) removal

101 and biogas production. By simulating adequately the global mass/volume and TS 
102 dynamics, the presented model might serve as a link between 'wet' AD and HS-AD,

103 while it might help to explore potential inhibitory/acidification mechanisms occurring

104 during HS-AD of OFMSW. Meanwhile, the proposed model was aimed to be as general

105 as possible, since different HS-AD applications (i.e. organic substrate and/or reactor

106 configuration) could be simulated, provided that the main hypotheses presented in the

107 methodology section are fulfilled. Furthermore, the eventual model user is encouraged

108 to further calibrate the model parameters and/or modify the model structure, in order to

109 adapt the HS-AD model for any specific need.

110

1112 MATERIALS AND METHODS

$112 \quad$ 2.1 High-Solids Model Implementation

113 The main basis for the dynamic model presented in this study was ADM1 (Batstone et

114 al. 2002), including the modifications suggested by Blumensaat and Keller (2005) for

115 closing nitrogen and carbon balances. The simulation of the HS-AD of OFMSW

116 required four preliminary hypotheses in order to reduce the complexity of the model.

117 Firstly, HS-AD was assumed to take place in a homogenized (i.e. completely mixed)

118 reactor [Hypothesis 1]. Secondly, the effect of porosity and transport processes was

119 assumed to be negligible [Hypothesis 2]. Then, the specific weight of solids and solvent

120 was considered constant [Hypothesis 3]. Finally, the biochemical reactions were

121 assumed to occur predominantly in water [Hypothesis 4].

122 With these hypotheses, ADM1 required some particular modifications in order to

123 simulate the TS and mass/volume dynamics in HS-AD, while allowing the calibration

124 of the proposed model. The main modifications implemented in ADM1 in order to

125 simulate HS-AD were the inclusion of mass balances modifying the reactor mass and 
126 volume (needed to account for the organic solid removal in HS-AD) and the inclusion

127 of apparent concentrations (as a link between 'wet' and high-solids applications).

128

\section{2.1.1 Mass Balances in High-Solid Anaerobic Digestion Reactors}

130 The simulation of the reactor mass and TS/VS content of homogenized HS-AD reactors

131 required the implementation of the global $\left(\mathrm{M}_{\text {Global }}\right)$ [Equation 1], solid material $\left(\mathrm{M}_{\text {Solids }}\right)$

132 [Equation 2], liquid-solvent content $\left(\mathrm{M}_{\text {Solvent }}\right)$ [Equation 3] and inert material $\left(\mathrm{M}_{\text {Inerts }}\right)$

133 [Equation 4] mass balances. In this study, the solvent was considered as only water,

134 while the solid material included all the organic and inorganic compounds (i.e.

135 particulates and soluble compounds, VFA, microorganisms) inside the reactor, except

136 water. In mass balances, the mass content $\left(\mathrm{M}_{\mathrm{i}}\right)$ - global or partial - dynamics were

137 related to the corresponding mass fluxes $\left(\mathrm{m}_{\mathrm{i}}\right)$, particularly the gases flowing out of the

138 reactor as a consequence of methanogenesis. The implementation of reactor mass

139 balances is crucial in HS-AD, since it accounts for the importance of mass and water

140 removal due to biogas production, in contrast to 'wet' AD (Henze et al. 1997,

141 Kayhanian and Tchobanoglous 1996, Richards et al. 1991).

$$
\begin{gathered}
\frac{d M_{\text {Global }}}{d t}=m_{\text {Influent,Global }}-m_{\text {Effluent,Global }}-m_{\text {Biogas }} \\
\frac{d M_{\text {Solids }}}{d t}=m_{\text {Influent,Solids }}-m_{E f f l u e n t, \text { Solids }}-\left(m_{\text {Biogas }}-m_{\text {Vapor }}\right) \\
\frac{d M_{\text {Solvent }}}{d t}=m_{\text {Influent,Solvent }}-m_{\text {Effluent,Solvent }}-m_{\text {Vapor }} \\
\frac{d M_{\text {Inerts }}}{d t}=m_{\text {Influent,Inerts }}-m_{\text {Effluent,Inerts }}
\end{gathered}
$$

143 The biogas ( $\left.m_{\text {Biogas }}\right)$ [Equation 5] and vapor ( $m_{\text {Vapor }}$ ) [Equation 6] outflows in the mass

144 balances were calculated from the volumetric biogas flow $\left(\mathrm{Q}_{\mathrm{g}}\right)$, obtained as shown in 
145 the CSTR implementation of ADM1 (Batstone et al. 2002), by using the molar gas

146 composition $\left(x_{i}\right)$ and the molecular weight $\left(M r_{i}\right)$ of each gaseous compound in the gas

147 phase. The biogas was assumed to be composed of $\mathrm{CH}_{4}, \mathrm{CO}_{2}, \mathrm{H}_{2}, \mathrm{H}_{2} \mathrm{O}$ and $\mathrm{NH}_{3}$. The

148 reactor headspace was assumed to be vapor saturated, being vapor pressure $\left(P_{v}\right)$

149 expressed as a function of temperature (T). On the other hand, an inert gas was added to

150 account for the initial flushing in $\mathrm{AD}$ experiments (i.e. by $\mathrm{N}_{2}$ ), assuming for it a

151 negligible liquid solubility. Importantly, the inert gas was not included in $\mathrm{m}_{\text {Biogas }}$

152 calculations. Once knowing the $\mathrm{M}_{\text {Global }}, \mathrm{M}_{\text {Solids }}$ and $\mathrm{M}_{\text {Inerts }}$, the TS and VS contents were

153 approximated in dynamic mode by using the corresponding definition (EPA 2001)

154 [Equations $7 \& 8$ ]. Noteworthy, TS and VS in the proposed model were dimensionless

155 (i.e. $\mathrm{kg}$ Solids/kg Total), varying from 0 to 1.

$$
\begin{gathered}
m_{\text {Biogas }}=\frac{P_{T} Q_{g}}{R T} \sum x_{i} M r_{i} \\
m_{\text {Vapor }}=\frac{P_{v} Q_{g}}{R T} M r_{H 2 O} \\
T S=\frac{M_{\text {Solids }}}{M_{\text {Global }}} \\
V S=\frac{M_{\text {Solids }}-M_{\text {Inerts }}}{M_{\text {Global }}}
\end{gathered}
$$

156

157 The liquid-gas transfer of gaseous species in the CSTR implementation of ADM1

158 depends on the ratio between the reactor content volume $\left(\mathrm{V}_{\text {Global }}\right.$; ' $\mathrm{V}_{\text {liq }}$ ' in ADM1) and

159 the gas volume $\left(\mathrm{V}_{\mathrm{g}}\right)$, while their sum yields the design/overall reactor volume $\left(\mathrm{V}_{\text {Reactor }}\right)$

160 (Batstone et al. 2002). Thus, since a considerable reduction of $\mathrm{V}_{\mathrm{Global}}$ - alongside $\mathrm{M}_{\mathrm{Global}}$

161 removal - can occur in HS-AD associated with methanogenesis, the reactor volume was

162 approximated by the specific weigh of the reactor content $\left(\rho_{\text {Global }}\right)$. Importantly, $\rho_{\text {Global }}$

163 varies also in HS-AD, as it gathers together the individual dynamics of all the mass 
164 compounds in the system (Kayhanian and Tchobanoglous 1996). Therefore, to simulate

$165 \rho_{\text {Global }}$, it is necessary to know the specific weight of all the materials within HS-AD $\left(\rho_{i}\right)$,

166 but also their corresponding mass fraction $\left(\mathrm{m}_{\mathrm{i}}\right)$ [Equation 9]. For simplicity, the

167 simulations in this study used a common specific weight for all the solid compounds

168 ( $\left.\rho_{\text {Solids }}\right)$ and a solvent specific weight $\left(\rho_{\text {Solvent }}\right)$. With these simplifications, the $V_{\text {Global }}$

169 dynamics could be approximated with Equation 10.

$$
\begin{gathered}
\frac{1}{\rho_{\text {Global }}}=\sum_{i} \frac{m_{i}}{\rho_{i}} \\
\frac{d V_{\text {Global }}}{d t}=\frac{1}{\rho_{\text {Solids }}} \cdot \frac{d M_{\text {Solids }}}{d t}+\frac{1}{\rho_{\text {Solvent }}} \cdot \frac{d M_{\text {Solvent }}}{d t}
\end{gathered}
$$

170

171 The distinction between mass and volume in the proposed model for homogenized HS-

$172 \mathrm{AD}$ reactors permitted the use of $\mathrm{ADM} 1$ volumetric units (i.e. $\mathrm{kmol} / \mathrm{m}^{3}$ ), while

173 implementing the different influent and effluent mass and/or volumetric flows when

174 operating HS-AD in (semi-)continuous mode. Finally, for illustrative purposes only, an

175 adaptive volumetric effluent $\left(\mathrm{Q}_{\text {Effluent }}\right)$ was added to the model - in terms of a

176 proportional controller - to maintain $\mathrm{V}_{\mathrm{Global}}$ if required. This strategy permitted to

177 compensate for the potential organic mass removal in HS-AD and, therefore, to stabilize

178 the HS-AD system, as further discussed in section 3.1. A schematic diagram of the HS-

179 AD model implementation for homogenized reactors is shown in Figure 2.

180

\subsubsection{Apparent Concentrations - Soluble Species Recalculation}

182 The (soluble) apparent concentrations $\left(\mathrm{S}_{\mathrm{T}, \mathrm{i}, \mathrm{App}}\right)$ were used in the HS-AD model

183 biochemistry and physicochemistry to reproduce the effect of high TS in HS-AD, in

184 contrast to 'wet' AD. This modification was related to the assumption that the main

185 biochemical reactions might occur predominantly in the presence of water (Hypothesis 
186 4). Similarly, the apparent concentrations served to link the global (i.e. kmol/kg Total)

187 and liquid fraction (i.e. $\mathrm{kmol} / \mathrm{kg}$ Solvent) measurements in HS-AD. The apparent

188 concentrations were calculated for all the soluble species of ADM1 using TS, $\rho_{\text {Global }}$ and

$189 \rho_{\text {Solvent }}\left[\right.$ Equation 11]. Importantly, the long chain fatty acids (LCFA, $\mathrm{S}_{\mathrm{fa}}$ ) were not

190 considered as soluble in HS-AD, due to their highly non-polar nature and reduced

191 solubility in water (i.e. palmitic acid solubility $=1.2 \mathrm{mg} / \mathrm{L}$ at $60^{\circ} \mathrm{C}$ ). With this approach,

192 the proposed model simulates the mass balance of dynamic variables $\left(\mathrm{C}_{\mathrm{T}, \mathrm{i}}\right)-$ either

193 particulate $\left(\mathrm{X}_{\mathrm{T}, \mathrm{i}}\right)$ or soluble $\left(\mathrm{S}_{\mathrm{T}, \mathrm{i}}\right)$ - as a function of $\mathrm{V}_{\mathrm{Global}}\left(\mathrm{i} . \mathrm{e} . \mathrm{kmol} / \mathrm{m}^{3}\right.$ Total $)$

194 [Equation 12], while the apparent concentrations $\left(S_{T, i, A p p}\right)\left(\right.$ i.e. $\mathrm{kmol} / \mathrm{m}^{3}$ Solvent $)$ were

195 used only for the soluble species included in the biochemical and physicochemical rates

196 of ADM1 ( $\left.\mathrm{r}_{\mathrm{i}, \mathrm{ADM} 1}\right)$ (i.e. uptake of acetate). It is important to mention that Equation 12 is

197 the mass balance of an individual component in AD and, therefore, should be based in

198 the chain rule in order to account for the $\mathrm{V}_{\mathrm{Global}}$ dynamics, in contrast to the CSTR

199 implementation of ADM1 (Batstone et al. 2002). On the other hand, it should be noted

200 that the effect of apparent concentrations becomes negligible at low TS contents (i.e. TS

$201<5 \%$ ) with $\rho_{\text {Global }}$ tending to $\rho_{\text {Solvent, }}$ as $S_{\mathrm{T}, \mathrm{i}, \mathrm{App}}$ progressively approaches to $\mathrm{S}_{\mathrm{T}, \mathrm{i}}$ in these

202 conditions. With all the above, the sole implementation of the HS-AD mass balances

203 and the use of apparent concentrations in this study might allow to simulate indistinctly

204 'wet' AD and HS-AD conditions, and/or the transition between these two AD regimes,

205 for example, during a prolonged HS-AD operation.

$$
S_{T, i, A p p}\left(\frac{\mathrm{kg} \text { or } \mathrm{kmol}}{\mathrm{m}^{3} \text { Solvent }}\right)=\frac{S_{T, i}\left(\frac{\mathrm{kg} \text { COD or } \mathrm{kmol}}{\mathrm{m}^{3} \text { Total }}\right)}{(1-\mathrm{TS})\left(\frac{\mathrm{kg} \text { Solvent }}{\mathrm{kg} \text { Total }}\right)} \cdot \frac{\rho_{\text {Solvent }}\left(\frac{\mathrm{kg} \text { Solvent }}{\mathrm{m}^{3} \text { Solvent }}\right)}{\rho_{\text {Global }}\left(\frac{\mathrm{kg} \text { Total }}{\mathrm{m}^{3} \text { Total }}\right)}
$$




$$
\begin{aligned}
\frac{d C_{T, i}}{d t}=\frac{1}{V_{\text {Global }}} & \cdot\left(Q_{\text {Influent }} \cdot C_{T, 0}-\frac{m_{\text {Effluent }}}{\rho_{\text {Global }}} \cdot C_{T, i}\right)+\sum r_{i, A D M 1}-\frac{C_{T, i}}{V_{\text {Global }}} \\
\cdot & \frac{d V_{\text {Global }}}{d t}
\end{aligned}
$$

\subsubsection{Kinetic Rates}

208 The ADM1 biochemical rates and inhibitions were used for the verification of the model implementation according to the protocol proposed by Rosén and Jeppsson

210 (2006). The model verification aimed to test/assess the ADM1 implementation (code)

211 alongside the adequate mathematical solution of the mass balances, determining the TS

212 and organic removal both in 'wet' and high-solids AD applications. On the other hand,

213 a slightly different set of biochemical rates was used for HS-AD model calibration.

214 Thus, calibration aimed to test/assess the HS-AD model performance under real

215 experimental conditions. The biochemical kinetics used in this study are shown in Table 2161.

217 The biochemical rates used in the HS-AD model were associated with the inhibitory

218 functions as originally proposed in ADM1 (Batstone et al. 2002, Rosén and Jeppsson

219 2006) [Equations 13 to 16]. However, all the soluble species terms included in the HS-

220 AD biochemical rates - excluding $S_{\mathrm{fa}}$ - were expressed in terms of apparent

221 concentrations, as mentioned in section 2.1.2.

$$
\begin{gathered}
I_{i n}=\frac{S_{i n, A p p}}{K_{S, S i n}+S_{i n, A p p}} \\
I_{h 2}=\frac{K_{i, S h 2}}{K_{i, S h 2}+S_{h 2, A p p}} \\
I_{p H}=\frac{K_{p H}{ }^{N_{p H}}}{K_{p H}{ }^{N_{p H}}+S_{p r o t o n}{ }^{N_{p H}}} \\
I_{n h 3}=\frac{K_{i, S n h 3}}{K_{i, S n h 3}+S_{n h 3, A p p}}
\end{gathered}
$$


223 Regarding the HS-AD model implementation used for calibration [Table 1], the valerate

224 uptake was assumed to be carried out by valerate degraders $\left(\mathrm{X}_{\mathrm{c} 5}\right)$, instead of butyrate

225 and valerate being both degraded by butyrate degraders $\left(\mathrm{X}_{\mathrm{c} 4}\right)$, as proposed in ADM1

226 (Batstone et al. 2002). This last modification was used to account for the different

227 dynamics observed for butyrate and valerate uptake in the experimental data. The valerate parameters and rates were maintained as in the original thermophilic $\left(55^{\circ} \mathrm{C}\right)$ implementation of ADM1, though the $\mathrm{X}_{\mathrm{c} 5}$ decay was included in the biochemical matrix. On the other hand, the microbial decay was assumed to yield particulate substances (i.e. carbohydrates and proteins) directly, avoiding the use of a composite material $\left(X_{c}\right)$ and the associated disintegration kinetics (Batstone et al. 2015). The biomass decay COD fractioning (i.e. $\mathrm{f}_{\mathrm{ch}, \mathrm{xc}}$ ) was maintained as proposed by Rosén and Jeppsson (2006). However, the inert materials (i.e. $S_{i}$ and $\left.X_{i}\right)$ carbon content $\left(C_{i}\right)$ was modified to $0.0405 \mathrm{kmol} \mathrm{C} / \mathrm{kg} \mathrm{COD}$ in order to close the biomass carbon balance, while

236 the inert nitrogen content $\left(\mathrm{N}_{\mathrm{i}}\right)$ was modified to $0.0144 \mathrm{kmol} \mathrm{N} / \mathrm{kg}$ COD to close the

237 biomass nitrogen balance. This last modification permitted to reduce the stiffness and

238 speed up the model simulations in this study.

239 The degradation of the protein content of an organic waste determines the total

240 ammonia nitrogen (TAN, $S_{\text {in }}$ ) in HS-AD (Kayhanian 1999). In this line, the nitrogen

241 balance has to be closed for the microorganisms in ADM1, while adding complex

242 substrates implies the fulfilment of the corresponding nitrogen balances. For this study,

243 two nitrogen balances were used for the biomass and substrate as shown in Equations

24417 and 18, respectively, assuming a common nitrogen content for proteins/amino acids

$245\left(\mathrm{~N}_{\mathrm{aa}}\right)$. With this approach, two new inert variables $\left(\mathrm{S}_{\mathrm{i}, \text { subs }}\right.$ and $\left.\mathrm{X}_{\mathrm{i}, \text { subs }}\right)$ were added to 
246 ADM1 in order to calibrate the initial protein content $\left(\mathrm{X}_{\mathrm{pr}}\right)$ and/or the experimental

247 TAN dynamics. The nitrogen balance for biomass [Equation 17] remained closed as

248 mentioned before, while the protein fraction of the substrate-inoculum mixture $\left(\mathrm{f}_{\mathrm{pr}, \mathrm{subs}}\right)$

249 could be adjusted by calibrating the inert nitrogen content of the substrate-inoculum

250 mixture $\left(\mathrm{N}_{\mathrm{i}, \text { subs }}\right)$, since all the remaining variables in the nitrogen balance $\left(\mathrm{N}_{\text {subs }}, \mathrm{f}_{\mathrm{si}, \text { subs }}\right.$

251 and $f_{x i \text { subs }}$ ) [Equation 18] could be obtained experimentally. For example, the anaerobic

252 biodegradability (i.e. $\mathrm{COD}_{\text {removed }} / \mathrm{COD}_{\text {substrate }}$ ) of an organic substrate is equivalent to 1 -

$253\left(f_{\text {si,subs }}+f_{\text {xi,subs }}\right)$, while the global nitrogen content of the substrate-inoculum mixture

$254\left(\mathrm{~N}_{\text {subs }}\right)$ is the quotient between the total Kjeldahl nitrogen (TKN) and COD (i.e.

$\left.255 \mathrm{TKN}_{\text {substrate }} / \mathrm{COD}_{\text {substrate }}\right)$.

$$
\begin{gathered}
N_{b a c}=f_{p r, x c} \cdot N_{a a}+\left(f_{s i, x c}+f_{x i, x c}\right) \cdot N_{i} \\
N_{\text {subs }}=f_{p r, \text { subs }} \cdot N_{a a}+\left(f_{\text {si,subs }}+f_{x i, \text { subs }}\right) \cdot N_{i, \text { subs }}
\end{gathered}
$$

\subsection{Verification of the Model Implementation}

258 The proposed model implementation was verified for 'wet' AD according to Rosén and

259 Jeppsson (2006). Similarly, the model was further tested for HS-AD conditions. In total,

260 four different verification scenarios were simulated: A) 'wet' AD using the ADM1

261 implementation of Rosén and Jeppsson (2006); B) 'wet' AD using the HS-AD model

262 implementation with a constant $\mathrm{Q}_{\text {Effluent }}$; ) HS-AD using the HS-AD model and

263 constant $\mathrm{Q}_{\text {Effluent }}$; and D) HS-AD considering the HS-AD model with an adaptive

264 QEffluent. The HS-AD model was coded in MATLAB ${ }^{\circledR}$ R2017a. The equation resolution

265 was the ode15s; a variable-step, variable-order solver based on the numerical

266 differentiation formulas of orders 1 to 5 . The influent conditions used for model

267 verification are shown in Table 2. 
268 Noteworthy, the only difference between the influent conditions during simulations A

269 and $\mathrm{B}$ was the introduction of the TS, VS and $\rho_{\text {Global }}$ of the substrate in the last case

270 [Table 2], permitting to excite the high-solids module of the proposed HS-AD model, in

271 contrast to the CSTR implementation of ADM1. On the other hand, for illustrative

272 purposes only, a high-solids substrate was included using a different carbohydrate $\left(\mathrm{X}_{\mathrm{ch}}\right)$

273 and particulate inert $\left(\mathrm{X}_{\mathrm{i}}\right)$ content, but also TS, VS and $\rho_{\text {Global }}$, for simulations $\mathrm{C}$ and $\mathrm{D}$

274 [Table 2]. Thus, the high TS content of the influent conditions (i.e. 25\%), associated

275 predominantly with $\mathrm{X}_{\mathrm{ch}}$ and $\mathrm{X}_{\mathrm{i}}$, permitted to test the model under HS-AD operation,

276 while avoiding potential inhibitory states due to $\mathrm{NH}_{3}$ accumulation.

277 During the verification of the model implementation, all the ADM1 parameters were

278 used as proposed by Rosén and Jeppsson (2006) for mesophilic $\left(35^{\circ} \mathrm{C}\right)$ AD operation,

279 though the original hydrolysis constant for carbohydrates $\left(\mathrm{k}_{\mathrm{h}, \mathrm{ch}}\right)$ had to be reduced to

2800.10 days in the HS-AD verification only (simulations $C$ and D), in order to avoid

281 reactor overloading and acidification (i.e. $\mathrm{pH} \leq 6.0$ ) during the initial days of

282 simulation. 200 days of 'wet' AD or HS-AD operation were simulated for each

283 verification scenario. The organic loading rate (OLR) was evaluated as the daily

284 substrate addition in COD units divided by $\mathrm{V}_{\mathrm{Global}}$, while the hydraulic retention time

285 (HRT) was evaluated as the quotient between $\mathrm{V}_{\text {Global }}$ and $\mathrm{Q}_{\text {Effluent }}$.

286

$287 \quad 2.3$ Experimental Data and Data Recalculation

288 The experimental data used to calibrate the HS-AD model consisted in a batch-sacrifice

289 test fed with dried OFMSW and centrifuged inoculum at TS of $15 \%$ operated under

290 thermophilic $\left(55^{\circ} \mathrm{C}\right)$ conditions. In the sacrifice test, 15 replicates were implemented in

$291250 \mathrm{~mL}$ serum bottles. Thus, after measuring the biogas volume and composition, a 
292 single replicate was opened, and the HS-AD content thoroughly analyzed for the main

293 physicochemical variables. The experimental results included the TS, VS, $\rho_{\text {Global }}, \mathrm{COD}$,

294 TKN, TAN, pH, volatile fatty acids (VFA; valeric, butyric, propionic and acetic acids),

295 mono-valent ions $\left(\mathrm{Na}^{+}, \mathrm{K}^{+}\right.$and $\left.\mathrm{Cl}^{-}\right)$, biogas composition $\left(\mathrm{CH}_{4}, \mathrm{CO}_{2}\right.$ and $\left.\mathrm{H}_{2}\right)$ and

296 methane yield. The serum bottles were agitated only on those days when the biogas

297 production was measured. Further information about the experimental setup, substrate,

298 inoculum and physicochemical analyses is presented as Supplementary Information.

299 Importantly, an experimental bias might exist on TS measurements whether volatile

300 compounds (i.e. $\mathrm{NH}_{3}, \mathrm{CO}_{2}$ and VFA) are lost when drying at $105^{\circ} \mathrm{C}$ (Angelidaki et al.

3012009 , EPA 2001). For this study, the mass of volatile substances at $105^{\circ} \mathrm{C}\left(\mathrm{M}_{\text {Volatiles }}\right)$

302 was assumed to be equivalent to the total mass of VFA $\left(S_{\mathrm{ac}}, \mathrm{S}_{\mathrm{pro}}, \mathrm{S}_{\mathrm{bu}}\right.$ and $\left.\mathrm{S}_{\mathrm{va}}\right), \mathrm{TAN}\left(\mathrm{S}_{\mathrm{in}}\right)$

303 and inorganic carbon $\left(\mathrm{S}_{\mathrm{ic}}\right)$ [Equation 19]. Thus, the simulated TS and VS were

304 recalculated a posteriori $\left(\mathrm{TS}_{\text {Recalc }}\right.$ and $\left.\mathrm{VS}_{\text {Recalc }}\right)$ [Equation 20 and 21] in order to

305 compare them with the experimental values.

$$
\begin{gathered}
M_{\text {Volatiles }}=\left(S_{a c} \cdot \frac{60}{64}+S_{\text {pro }} \cdot \frac{74}{112}+S_{\text {bu }} \cdot \frac{88}{160}+S_{v a} \cdot \frac{102}{208}+S_{\text {in }} \cdot 17+S_{\text {ic }}\right. \\
\cdot 44) \cdot V_{\text {Global }} \\
T S_{\text {Recalc }}=\frac{M_{\text {Solids }}-M_{\text {Volatiles }}}{M_{\text {Global }}} \\
V S_{\text {Recalc }}=\frac{M_{\text {Solids }}-M_{\text {Inerts }}-M_{\text {Volatiles }}}{M_{\text {Global }}}
\end{gathered}
$$

306

307

\subsection{Model Calibration}

308 The calibration of some of the main biochemical parameters in this study aimed to

309 obtain the best fitting with the experimental data for a homogenized HS-AD laboratory-

310 scale reactor, in order to assess the correct simulations of the TS and reactor content

311 dynamics. The model calibration was carried out by trial and error, mainly for the 
312 hydrolysis (i.e. $\mathrm{k}_{\mathrm{h}, \mathrm{h}}$ ) and maximum growth rate (i.e. $\mathrm{k}_{\mathrm{m}, \mathrm{su}}$ ) constants, aiming to maintain

313 as close as possible the parameters proposed for thermophilic $\left(55^{\circ} \mathrm{C}\right) \mathrm{AD}$ in ADM1

314 (Batstone et al. 2002). Noteworthy, the initial composition (i.e. $S_{\text {ac }}, S_{\text {in }}$ ) was chosen

315 based on the evaluation of the experimental data available (i.e. VFA, TAN), while all

316 the initial microorganisms concentrations (i.e. $\mathrm{X}_{\mathrm{ac}}, \mathrm{X}_{\mathrm{su}}$ ) were calibrated also by trial and

317 error, alongside the main biochemical parameters, as further discussed in section 3.2.1.

318

3193 RESULTS AND DISCUSSION

$320 \quad 3.1$ Model Implementation Verification

$321 \quad 3.1 .1$ 'Wet' AD Verification

322 The model verification for 'wet' AD operating in a CSTR (simulation A) showed

323 minimal differences (i.e. $4^{\text {th }}-5^{\text {th }}$ significant digit) compared to the results suggested by

324 Rosén and Jeppsson (2006) [Table 3], being these differences likely associated with the

325 slightly different equation resolution method used [U. Jeppsson, Personal

326 Communication]. Importantly, when using the HS-AD model implementation for 'wet'

327 AD (simulation $\mathrm{B}$ ), the results were again very close to the original 'wet' ADM1

328 verification, though some differences could be observed for all the dynamic variables

329 [Table 3]. For example, the acetic acid $\left(\mathrm{S}_{\mathrm{ac}}\right)$ predicted with the HS-AD model

330 implementation (simulation B) was around $39 \%$ higher than that in the original ADM1

331 (simulation A). The TS concentration effect of apparent concentrations might define

332 some differences among all the soluble species during 'wet' AD (i.e. $S_{\mathrm{ac}}, \mathrm{S}_{\mathrm{h} 2}, \mathrm{~S}_{\mathrm{nh} 3}$ ),

333 though the apparent concentrations effect in 'wet' applications was relatively small in

334 simulation B due to the low TS content (i.e. $<5 \%$ ) [Equation 11]. 
335 It is important to mention that the differences between simulations A and B were related

336 to the fact that the 'wet' AD simulation using the HS-AD model (simulation B) did not

337 reach steady-state. Thus, a steady-state operation in simulation B was not reached even

338 after 200 days, particularly due to the implementation of a common volumetric

339 influent/effluent (i.e. $Q_{\text {Influent }}=Q_{\text {Effluent }}$ ). In this line, simulation B showed an overall

$34037 \%$ reduction in the TS content after 200 days, as well as a $13 \%$ reduction in the

$341 \mathrm{~V}_{\text {Global }}$ (but also HRT), and a $0.5 \%$ reduction in $\rho_{\text {Global }}$ [Table 3]. Therefore, a daily-

342 averaged $0.06 \% \mathrm{~V}_{\text {Global }}$ modification occurred in 'wet' AD using the HS-AD model,

343 which might be considered negligible for short operation periods, but increasingly

344 important for longer operation (Henze et al. 1997, Richards et al. 1991). The

345 progressive reduction of the HRT during simulation B led to a proportional increase in

346 the OLR from 2.85 to $3.27 \mathrm{~kg} \mathrm{COD} / \mathrm{m}^{3} \cdot \mathrm{d}$ [Figure 3a], explaining the differences

347 between simulations $A$ and B (i.e. $S_{a c}$ ) mentioned before. Interestingly, the reduction in

$348 \rho_{\text {Global }}\left(\right.$ i.e. $0.994 \mathrm{~kg} / \mathrm{L}$ ) below $\rho_{\text {Solvent }}($ i.e. $1.000 \mathrm{~kg} / \mathrm{L}$ ) suggests that the influent

349 conditions (i.e. $\rho_{\text {Global0 }}=\rho_{\text {Solvent }}$ ) and/or the model simplifications (i.e. $\rho_{\text {Solids }}=$ const.)

350 required further testing.

351 The specific weight of a complex sample $\left(\rho_{\text {Global }}\right)$ depends on all the compounds

352 involved [Equation 9]. Since the measurement of all the variables $\rho_{\mathrm{i}}$ in an AD sample is

353 rarely available, the $\rho_{\mathrm{i}}$ of each compound needs to be known/assumed for simulations.

354 In this line, the specific weight of a sample solid fraction ( $\left.\rho_{\text {Solids }}\right)$ can be approximated

355 by knowing the specific weight of the solvent $\left(\rho_{\text {Solvent }}\right)$, though $\rho_{\text {Solvent }}$ is again function

356 of all the different compounds in solution, as well as a function of temperature and

357 pressure (Lide 2004). As a preliminary approach, $\rho_{\text {Solvent }}$ was assumed to be close to the

358 specific weight (density) of water at $0{ }^{\circ} \mathrm{C}$ and 1 bar (i.e. $\rho_{\text {Solvent }}=1 \mathrm{~kg} / \mathrm{L}$ ), since the 
359 density of water is $999.84 \mathrm{~kg} / \mathrm{m}^{3}$ at $0{ }^{\circ} \mathrm{C}, 993.64 \mathrm{~kg} / \mathrm{m}^{3}(0.63 \%$ error $)$ at $35^{\circ} \mathrm{C}$, and

$360985.19 \mathrm{~kg} / \mathrm{m}^{3}$ (1.48 \% error) at $55^{\circ} \mathrm{C}$ (Kell 1975, Lide 2004), thus being approximately

361 constant at any of these temperatures. With this strategy, the specific weights obtained

362 for the overall sample $\left(\rho_{\text {Global }}\right)$ and/or the solid fraction $\left(\rho_{\text {Solids }}\right)$ were considered relative

363 regarding the specific weight of solvent $\left(\rho_{\text {Solvent }}\right)$. Meanwhile, $\rho_{\text {Solvent }}$ (but also $\left.\rho_{\text {Solids }}\right)$

364 could be set to any value, or modified by any expression (i.e. as a function of

365 temperature), without modifying the structure of the model. Thus, once knowing the

$366 \rho_{\text {Solvent }}$, the $\rho_{\text {Global }}$ and TS of a (semi-)solid sample, $\rho_{\text {Solids }}$ could be approximated by

367 using the mass balance [Equation 9].

368 Previous research indicated that $\rho_{\text {Solids }}$ ranges from $1.3 \mathrm{~kg} / \mathrm{L}$ in lignocellulosic materials

369 to $1.5 \mathrm{~kg} / \mathrm{L}$ in OFMSW and $2.5 \mathrm{~kg} / \mathrm{L}$ for inorganic inert solids (i.e. sand). On the other

370 hand, the specific weight of microorganisms is reported between 0.8 and $1.4 \mathrm{~kg} / \mathrm{L}$ (van

371 Veen and Paul 1979), though this fraction might be a negligible part (i.e. $5 \%$ ) of the

372 whole reactor mass content. Therefore, a compromise value of $\rho_{\text {Solids }}=1.5 \mathrm{~kg} / \mathrm{L}$ was

373 chosen for the preliminary model verification/calibration, though further testing must be

374 devoted to this particular variable, since it could influence other aspects of the HS-AD

375 simulations (i.e. $\mathrm{V}_{\text {Global }}$ ), as mentioned before.

376

\section{$377 \quad$ 3.1.2 HS-AD Verification}

378 Regarding the HS-AD model verification with constant QEffluent (simulation C), the HS-

379 AD simulation did not reach the steady state after 200 days, while longer simulations

380 (i.e. 365 days) yielded reactor acidification (i.e. $\mathrm{pH} \leq 6.0$ ) - data not shown. This is due

381 to a progressive reduction of $\mathrm{V}_{\mathrm{Global}}$ in $\mathrm{HS}-\mathrm{AD}$ when maintaining a volumetric outflow

382 equal to the volumetric inflow (i.e. $\left.\mathrm{Q}_{\text {Influent }}=\mathrm{Q}_{\text {Effluent }}\right)($ Kayhanian and Tchobanoglous 
383 1996, Richards et al. 1991). Thus, the HRT decreases - and the OLR increases -

384 proportionally to the $\mathrm{V}_{\text {Global }}$ reduction in HS-AD until the 'washout' of methanogens

385 occurs and the reactor acidifies. For example, a $50 \%$ reduction in HRT was observed

386 with the influent conditions tested in simulation C [Figure 3b], with an approximately

387 daily-averaged $\mathrm{V}_{\text {Global }}$ reduction of $0.25 \%$.

388 Meanwhile, a rapid stabilization of the HS-AD process was obtained when choosing a 389 constant reactor volume as a set point (i.e. $\mathrm{V}_{\text {Setpoint }}=\mathrm{V}_{\text {Global0}}$ ) and recalculating $\mathrm{Q}_{\text {Effluent }}$

390 [Table 3 and Figure 3b]. Noteworthy, the QEffluent recalculation operation yielded a

391 reduction of around $5.6 \%$ of the steady-state value regarding $Q_{\text {Influent }}$, and a $24 \%$ TS

392 removal compared to the substrate TS (i.e. from 25 to $19 \%$ ). These results condense the

393 importance of reducing the effluent compared to the influent (i.e. $Q_{\text {Influent }}>Q_{\text {Effluent }}$ ) to

394 reach steady-state HS-AD, in order to compensate the organic removal by

395 methanogenesis (Kayhanian and Hardy 1994, Kayhanian and Tchobanoglous 1996,

396 Richards et al. 1991). Furthermore, the use of apparent concentrations might be also

397 crucial for HS-AD simulations, since practically all the biochemical rates were affected

398 (i.e. speeded-up/slowed-down) by the TS concentration effect on soluble substrates (i.e.

$399 \mathrm{~S}_{\mathrm{ac}}$ ) and/or inhibitors (i.e. $\mathrm{S}_{\mathrm{nh} 3}$ ) [Table 1]. For example, a $26 \%$ increase in all the

400 soluble concentrations (i.e. $\mathrm{S}_{\mathrm{su}}$ and $\mathrm{S}_{\mathrm{h} 2}$ ) was obtained by the tested HS-AD conditions in

401 steady-state operation - data not shown.

402 The water/solvent in this study was assumed to be conservative, since the same water

403 entering leaves the system as a liquid effluent ( $\left.m_{\text {Effluent,Solvent }}\right)$ or vapor ( $\left.\mathrm{m}_{\mathrm{Vapor}}\right)$, but is

404 not produced/consumed. Importantly, production/consumption of water in the

405 biochemical processes (i.e. hydrolysis, methanogenesis) might occur, linking Equations

4062 and 3. However, the production/consumption of water is tightly linked to the 
407 stoichiometry of all the reactions occurring in HS-AD, while the stoichiometry of all the

408 biochemical reactions in ADM1 requires further development (De Gracia et al. 2006,

409 Kleerebezem and van Loosdrecht 2006, Rodríguez et al. 2006). Therefore, using

410 Equations 1 to 4 is a reasonable hypothesis that can be modified, once the global

411 stoichiometry of HS-AD is well-defined. In this last case, the Petersen matrix originally

412 proposed for ADM1 would need to account for water as another dynamic variable. For

413 example, De Gracia et al. (2006) included water (i.e. $\mathrm{S}_{\mathrm{h} 2 \mathrm{o}}$ ) in the Petersen matrix of

414 ADM1, though the AD stoichiometry was partially assumed (i.e. elemental

415 composition). Furthermore, in order to use Equations 1 to 4 in this study, it was also

416 assumed that the organic solid destruction only proceeds when biogas production

417 occurs. In other words, whether hydrolysis, acidogenesis and/or acetogenesis occur, but

418 not biogas production (i.e. $\mathrm{CH}_{4}, \mathrm{CO}_{2}$ and/or $\mathrm{H}_{2}$ ), complex substrates (i.e. carbohydrates)

419 are just transformed into more simple substrates (i.e. sugars, VFA), being both of them

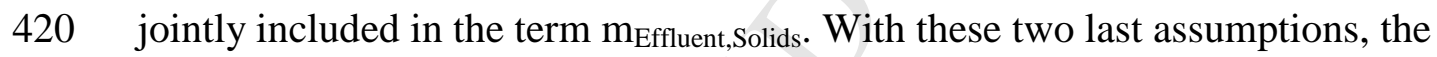

421 hydrolysis to acidogenesis steps were not included in Equations 1 to 4 . However, the

422 mass volatile compounds at $105^{\circ} \mathrm{C}$ ( $\left.\mathrm{M}_{\text {Volatiles }}\right)$ needed to be accounted in the TS and VS

423 calculations, as shown in Equations 19 to 21.

424 Due to the considerably higher COD of the influent conditions [Table 2], the OLR was

425 around 7 times higher for HS-AD than for 'wet' AD simulations [Table 3], which

426 directly relates to the higher chances of HS-AD acidification, and the necessity to

427 reduce considerably the $\mathrm{k}_{\mathrm{h}, \mathrm{ch}}$ for HS-AD simulations. In either case, HS-AD

428 experimental data are required to calibrate biochemical parameters (i.e. $\mathrm{k}_{\mathrm{h}, \mathrm{ch}}$ ).

$430 \quad 3.2$ Model Calibration 
431

432

433

434

435

436

437

438

440

441

442

443

444

445

446

447

448

449

450

451

452

\subsubsection{Comparison Between Simulated and Experimental Values}

The HS-AD simulation of OFMSW in batch conditions at $15 \%$ TS closely matched all the experimental variables [Figure 4], though slight disagreements were also observed between the experimental data and the simulated values. The initial conditions and modified parameters used are shown in Tables 2 and 4, respectively. Firstly, the cumulative methane production was $830 \mathrm{NmL} \mathrm{CH}_{4}$ [Figure 4a], coinciding to that obtained experimentally, while the biogas composition was also well simulated - data not shown. Importantly, the overall biogas production was associated with $1.7 \mathrm{~g} \mathrm{M}_{\text {Global }}$ removal (i.e. $4.6 \%$ ), in agreement with the 1.5 - $2.0 \mathrm{~g}$ that could have been removed according to the experimental biogas flow/composition. Noteworthy, the simulation suggested that $\rho_{\text {Global }}$ was reduced from 1078 to $1064 \mathrm{~kg} / \mathrm{m}^{3}$ (i.e. $1.2 \%$ reduction) along the whole experimental period (data not shown), though the $\rho_{\text {Global }}$ modification should be further validated with experimental data, as discussed before. The $\mathbf{M}_{\text {Global }}$ and $\rho_{\text {Global }}$ modification yielded a $\mathrm{V}_{\text {Global }}$ reduction of $3.5 \%$ - data not shown.

The initial composition in the batch experiment [Table 2] was based on the availability of experimental data (i.e. $\mathrm{COD}, \mathrm{TS}$ and $\mathrm{CH}_{4}$ yield), but also on a reasoned assessment of the substrate and/or inoculum composition. For example, the protein content of the substrate/inoculum mixture (i.e. $\mathrm{X}_{\mathrm{pr}}+\mathrm{S}_{\mathrm{aa}}$ ) was adjusted according to the nitrogen content of proteins and amino acids $\left(\mathrm{N}_{\mathrm{aa}}\right)$ [Table 4] and the inert materials (i.e. $\mathrm{X}_{\mathrm{i}}+\mathrm{S}_{\mathrm{i}}$ ) to simulate the TAN $\left(S_{\text {in }}\right)$ dynamics, as mentioned in section 2.1.3. Unfortunately, apart from the $\mathrm{CH}_{4}$ yield and COD of the initial mixture, no data were available regarding the remaining complex substances (i.e. particulates) involved in the biochemical framework of the model. Therefore, the distinction between the initial carbohydrate/sugars $\left(\mathrm{X}_{\mathrm{ch}} / \mathrm{S}_{\mathrm{su}}\right)$ 
454 and lipids/LCFA $\left(\mathrm{X}_{\mathrm{g}} / \mathrm{S}_{\mathrm{fa}}\right)$ had to be tuned alongside the biochemical parameters to

455 simulate the initial days of the batch setup.

456 During the initial 20 days of experiment, $\mathrm{pH}$ was observed to drop from 7.3 to 6.3 -

457 data not shown - due to VFA accumulation [Figure 4b]. Thus, the initial VFA and pH

458 dynamics were simulated by a plausible set of microorganism concentrations,

459 hydrolysis constants and initial substrate/inoculum fractionation [Tables 2 and 4]. The

460 initial microbial concentrations are crucial in the simulation of AD batch experiments,

461 though they are normally unknown due to the difficulties for measuring the populations

462 involved (Donoso-Bravo et al. 2011, Flotats et al. 2010). Importantly, the hydrolysis

463 constants $\left(\mathrm{k}_{\mathrm{h}}\right)$ were considerably reduced compared to the original values proposed in

464 ADM1 for thermophilic $\left(55^{\circ} \mathrm{C}\right)$ operation (i.e. $\mathrm{k}_{\mathrm{h}, \mathrm{ch}}=0.05 \mathrm{~d}^{-1}$ vs. $10 \mathrm{~d}^{-1}$, respectively),

465 though the calibrated values were in accordance with reported hydrolysis rates for

466 simulation of OFMSW (Batstone et al. 2002, Kayhanian 1995, Mata-Alvarez 2003,

467 Vavilin and Angelidaki 2005).

468 In order to obtain the best fitting between the simulated and experimental VFA

469 dynamics from day 20 , the maximum growth rate $\left(\mathrm{k}_{\mathrm{m}}\right)$ of some microbial populations

470 was also considerably reduced. For example, the maximum growth rate of propionate

471 degraders $\left(\mathrm{k}_{\mathrm{m} \text {,pro }}\right)$ was reduced to $1 \mathrm{~d}^{-1}$, in contrast to the $20 \mathrm{~d}^{-1}$ proposed by ADM1 for

472 thermophilic $\left(55^{\circ} \mathrm{C}\right)$ operation [Table 4]. Noteworthy, the extremely low $\mathrm{k}_{\mathrm{m}}$ used for

473 model calibration, in contrast to the original values of ADM1, might be suggesting that

474 some inhibition in the VFA uptake was occurring in the experiment. Thus, $\mathrm{NH}_{3}$ reached

475 particularly high contents in the reactor (i.e. $0.16 \mathrm{~mol} \mathrm{~N} / \mathrm{kg}$ ) [Figure $4 \mathrm{c}$ ] mainly due to

476 the high $\mathrm{pH}$ observed (i.e. $\geq 8.0$ ), while $\mathrm{NH}_{3}$ is a well-known inhibitor of acetoclastic

477 and hydrogenotrophic methanogens (Angelidaki and Ahring 1993, Gallert and Winter 
478 1997, Jokela and Rintala 2003). In this line, the implementation of reversible $\mathrm{NH}_{3}$

479 inhibition [Equation 16] in hydrogen uptake could match adequately all the VFA, since

480 valerate and propionate degraders are inhibited by $\mathrm{H}_{2}$ buildup in ADM1 (Batstone et al.

481 2002). However, this last strategy led to $\mathrm{H}_{2}$ accumulation in the gas phase (i.e. 2 - $5 \%$,

482 data not shown), though no $\mathrm{H}_{2}$ was detected experimentally. Therefore, all the VFA-

483 degrading populations might be affected in some degree by $\mathrm{NH}_{3}$ accumulation, as

484 suggested by Poggi-Varaldo et al. (1997).

485 The model suggested a $5-15 \%$ difference between the simulated and experimental TS 486 and VS contents, despite the experimental trends were well approximated in both cases

487 [Figure 4d]. Therefore, since the simulated $\mathrm{M}_{\mathrm{Global}}, \mathrm{CH}_{4}$ yield and COD showed good

488 simulations, an experimental bias was suspected in the experimental TS/VS

489 measurement. Noteworthy, the recalculated TS and VS [Equations 19 to 21] improved

490 considerably the matching of the TS and VS simulations with the values observed

491 experimentally, though some differences were also observed from day 20 onwards.

492 Meanwhile, the TS and VS recalculation is supported by the fact that some organic

493 material (i.e. VFA), ammonia nitrogen (i.e. $\mathrm{NH}_{3}$ ) and/or inorganic carbon (i.e. $\mathrm{CO}_{2}$ )

494 might volatilize when drying the samples at $105^{\circ} \mathrm{C}$ for prolonged periods of time (i.e.

49524 h) (Angelidaki et al. 2009, EPA 2001). With all the above, the observed differences

496 between the TS and VS recalculated and experimental values [Figure 4d] were likely

497 related to the differences in the propionate and valerate simulations [Figure 4b] during

498 the same period. Therefore, the model calibration might require further improvement as

499 also discussed in next section.

500 
502 The model calibration in this study was aimed to be minimal because of: 1) the

503 complexity of HS-AD vs. the assumptions taken (i.e. homogenized reactor); 2) the little

504 data available regarding solids mass dynamics (i.e. TS/VS); 3) the high number of

505 biochemical parameters involved (i.e. > 10); and 4) the 'strong' interrelationship

506 between parameters and the initial conditions in structured AD models (Batstone et al.

507 2015, Donoso-Bravo et al. 2011, Flotats et al. 2010, Vanrolleghem et al. 1995). Thus,

508 the calibration in this study was mainly addressed to the simultaneous fitting of the

509 overall dynamics of TS/VS removal, reactor mass, biogas production, VFA and $\mathrm{pH}$, in

510 order to assess the potentiality of the proposed model to simulate a homogenized HS-

511 AD matrix.

512 The parameter modification compared to ADM1 values [Table 4] was needed to obtain

513 an adequate fitting of the overall set of experimental data for the sacrifice test in this

514 study. Importantly, most of the biochemical parameters modified were within the

515 recommended range suggested in ADM1, with the exception of the maximum

516 propionate and valerate growth rates (i.e. $\mathrm{k}_{\mathrm{m} \text {,pro }}$ and $\mathrm{k}_{\mathrm{m} \text {,va }}$ ) that could be associated to

$517 \mathrm{NH}_{3}$ inhibition, as mentioned in section 3.2.1. For example, the lower and upper $\mathrm{pH}$

518 levels for acetate uptake $\left(\mathrm{pH}_{\mathrm{LL}, \mathrm{ac}}\right.$ and $\mathrm{pH}_{\mathrm{UL}, \mathrm{ac}}$, respectively) might vary around $30 \%$

519 from the values proposed in $\mathrm{ADM} 1$ (i.e. $\mathrm{pH}_{\mathrm{LL}, \mathrm{ac}}=6.0$ and $\mathrm{pH}_{\mathrm{UL}, \mathrm{ac}}=7.0$ ) (Batstone et al.

520 2002). However, it must be highlighted that the implementation of a single experimental

521 dataset was not enough to calibrate a large number of parameters since, for example,

522 different combinations of biochemical parameters and/or initial conditions (i.e.

523 microorganisms) could yield practically the same agreement between experimental and

524 simulated results (Girault et al. 2011, Jablonski and Lukaszewicz 2014, Vanrolleghem

525 et al. 1995, Vavilin et al. 2008). Therefore, more experimental datasets (i.e. laboratory 
and/or large scale applications) are needed to refine the calibration of the proposed parameters for HS-AD of OFMSW. Meanwhile, a sensitivity analysis and an adequate parameter optimization strategy might reveal important aspects about the main biochemical and physicochemical processes occurring in HS-AD of OFMSW. With all the above, the minimal model calibration showed the potentiality of using adequately the mass balances alongside the biochemical framework of ADM1 to simulate HS-AD of OFMSW. Thus, the HS-AD model simulates particularly well the TS, VS, and $\mathrm{M}_{\text {Global }}$ dynamics of HS-AD, provided the four preliminary hypotheses proposed are fulfilled. Meanwhile, further studies are needed in order to improve the biochemical calibration of the HS-AD model, with the aim to explore the different acidification/inhibitory mechanisms of HS-AD fed with OFMSW. Further calibration will be also helpful to double check the hypotheses used, assess the HS-AD model performance and/or highlight potential areas requiring further model development. Summarizing, the user could calibrate the model parameters and/or readapt the HS-AD model structure as required for any particular HS-AD application.

\section{CONCLUSIONS}

In this study, a novel ADM1-based model was developed to simulate the solids and reactor mass/volume dynamics of homogenized HS-AD reactors. An adequate mass balance implementation condensed the effects of biogas production on HS-AD mass/volume, being critical to simulate relatively long operations. Apparent concentrations accounted for the TS concentration effect on soluble species. The model was verified for 'wet' $\mathrm{AD}$ and HS-AD, serving as a link between both operational regimes. The model simulated particularly well HS-AD of OFMSW in batch, including 
550 the TS and reactor mass, while further model calibration might serve to assess

551 inhibitory mechanisms in HS-AD of OFMSW.

552

553 Acknowledgements

554 This project has received funding from the European Union's Horizon 2020 research

555 and innovation programme under the Marie Sklodowska-Curie grant agreement No.

556 643071. The authors thank Ulf Jeppsson for his inestimable comments when verifying

557 the ADM1 implementation. 


\section{REFERENCES}

Abbassi-Guendouz, A., Brockmann, D., Trably, E., Dumas, C., Delgenes, J.P., Steyer, J.P. and Escudie, R. (2012) Total solids content drives high solid anaerobic digestion via mass transfer limitation. Bioresour. Technol. 111, 55-61.

Angelidaki, I. and Ahring, B.K. (1993) Thermophilic anaerobic digestion of livestock waste: the effect of ammonia. Appl. Microbiol. Biotechnol. 38(4), 560-564.

Angelidaki, I., Alves, M., Bolzonella, D., Borzacconi, L., Campos, J.L., Guwy, A.J., Kalyuzhnyi, S., Jenicek, P. and van Lier, J.B. (2009) Defining the biomethane potential (BMP) of solid organic wastes and energy crops: a proposed protocol for batch assays. Water Sci. Technol. 59(5), 927-934.

ASTM (2002) D854-02: Standard test methods for specific gravity of soil solids by water pycnometer, ASTM International, American Society for Testing and Materials, United States.

Batstone, D.J. (2006) Mathematical modelling of anaerobic reactors treating domestic wastewater: rational criteria for model use. Rev. Environ. Sci. Bio. 5(1), 57-71.

Batstone, D.J., Keller, J., Angelidaki, I., Kalyuzhnyi, S.V., Pavlostathis, S.G., Rozzi, A., Sanders, W.T., Siegrist, H. and Vavilin, V.A. (2002) The IWA Anaerobic Digestion Model No. 1 (ADM1). Water Sci. Technol. 45(10), 65-73.

Batstone, D.J., Puyol, D., Flores-Alsina, X. and Rodríguez, J. (2015) Mathematical modelling of anaerobic digestion processes: applications and future needs. Rev. Environ. Sci. Bio. 14(4), 595-613.

Benbelkacem, H., Bollon, J., Bayard, R., Escudié, R. and Buffière, P. (2015) Towards optimization of the total solid content in high-solid (dry) municipal solid waste digestion. Chem. Eng. J. 273, 261-267.

Benbelkacem, H., Garcia-Bernet, D., Bollon, J., Loisel, D., Bayard, R., Steyer, J.P., Gourdon, R., Buffiere, P. and Escudie, R. (2013) Liquid mixing and solid segregation in high-solid anaerobic digesters. Bioresour. Technol. 147, 387-394.

Blumensaat, F. and Keller, J. (2005) Modelling of two-stage anaerobic digestion using the IWA Anaerobic Digestion Model No. 1 (ADM1). Water Res. 39(1), 171-183.

Bollon, J., Benbelkacem, H., Gourdon, R. and Buffière, P. (2013) Measurement of diffusion coefficients in dry anaerobic digestion media. Chem. Eng. Sci. 89, 115119.

Cecchi, F., Pavan, P., Battistoni, P., Bolzonella, D. and Innocenti, L. (2002) Characteristics of the organic fraction of municipal solid wastes in Europe for different sorting strategies and related performances of the anaerobic digestion process, Mérida, Yucatán.

Chen, Y., Cheng, J.J. and Creamer, K.S. (2008) Inhibition of anaerobic digestion process: a review. Bioresour. Technol. 99(10), 4044-4064.

De Baere, L. (2000) Anaerobic digestion of solid waste: state-of-the-art. Water Sci. Technol. 41(3), 283-290.

De Baere, L. and Mattheeuws, B. (2013) Waste Management: Recycling and Recovery. Thomé-Kozmiensky Karl J., T.S. (ed), pp. 517-526.

De Gracia, M., Sancho, L., García-Heras, J.L., Vanrolleghem, P. and Ayesa, E. (2006) Mass and charge conservation check in dynamic models: application to the new ADM1 model. Water Sci. Technol. 53(1), 225-240. 
604 Donoso-Bravo, A., Mailier, J., Martin, C., Rodriguez, J., Aceves-Lara, C.A. and Vande

605

606

607

608

609

610

611

612

613

614

615

616

617

618

619

620

621

622

623

624

625

626

627

628

629

630

631

632

633

634

635

636

637

638

639

640

641

642

643

644

645

646

647

648

649 Wouwer, A. (2011) Model selection, identification and validation in anaerobic digestion: a review. Water Res. 45(17), 5347-5364.

EPA (2001) Method 1684. Total, fixed and volatile solids in water, solids, and biosolids., U.S. Environmental Protection Agency (EPA), Washington, DC.

Flotats, X., Palatsi, J., Fernandez, B., Colomer, M.A. and Illa, J. (2010) Identifying anaerobic digestion models using simultaneous batch experiments. Environ. Engineer. Manag. J. 9(3), 313-318.

Gallert, C. and Winter, J. (1997) Mesophilic and thermophilic anaerobic digestion of source-sorted organic wastes: effect of ammonia on glucose degradation and methane production. Appl. Microbiol. Biotechnol. 48, 405-410.

Girault, R., Rousseau, P., Steyer, J.P., Bernet, N. and Béline, F. (2011) Combination of batch experiments with continuous reactor data for ADM1 calibration: application to anaerobic digestion of pig slurry. Water Sci. Technol. 63(11), 2575.

Henze, M., Harremoes, P., Jansen, J.1.C. and Arvin, E. (1997) Wastewater treatment. Biological and chemical processes, Springer, Berlin.

Jablonski, S.J. and Lukaszewicz, M. (2014) Mathematical modelling of methanogenic reactor start-up: importance of volatile fatty acids degrading population. Bioresour. Technol. 174, 74-80.

Jokela, J.P. and Rintala, J. (2003) Anaerobic solubilisation of nitrogen from municipal solid waste (MSW). Rev. Environ. Sci. Bio. 2, 67-77.

Kayhanian, M. (1995) Biodegradability of the organic fraction of municipal solid waste in a high-solids anaerobic digester. Waste Manage. Res. 13, 123-136.

Kayhanian, M. (1999) Ammonia inhibition in high-solids biogasification: an overview and practical solutions. Environ. Technol. 20(4), 355-365.

Kayhanian, M. and Hardy, S. (1994) The impact of four design parameters on the performance of a high-solids anaerobic digestion of municipal solid waste for fuel gas production. Environ. Technol. 15(6), 557-567.

Kayhanian, M. and Tchobanoglous, G. (1996) Develogment of a mathematical model for the simulation of the biodegradation of organic substrates in a high-solids anaerobic digestion. J. Chem. Tech. Biotechnol. 66, 312-322.

Kell, G.S. (1975) Density, thermal expansivity, and compressibility of liquid water from 0 to $150^{\circ} \mathrm{C}$ : Correlations and tables for atmospheric pressure and saturation reviewed and expressed on 1968 temperature scale. J. Chem. Eng. Data 20(1), 97105.

Kleerebezem, R. and van Loosdrecht, M.C.M. (2006) Critical analysis of some concepts proposed in ADM1. Water Sci. Technol. 54(4), 51-57.

Lide, D.R. (2004) Hanbook of chemistry and physics, CRC Press.

Mata-Alvarez, J. (2003) Biomethanization of the organic fraction of municipal solid wastes, IWA Publishing, London, UK.

Mata-Alvarez, J., Macé, S. and Llabrés, P. (2000) Anaerobic digestion of organic solid wastes. An overview of research achievements and perspectives. Bioresour. Technol. 74(1), 3-16.

Pavan, P., Battistoni, P., Mata-Alvarez, J. and Cecchi, F. (2000) Performance of thermophilic semi-dry anaerobic digestion process changing the feed biodegradability. Water Sci. Technol. 41(3), 75-81. 
650

651

652

653

654

655

656

657

658

659

660

661

662

663

664

665

666

667

668

669

670

671

672

673

674

675

676

677

678

679

680

681

682

683

684

685

686

687

688

689

690

691

692

693

694

695

696

697

Poggi-Varaldo, H.M., Valdés, L., Esparza-García, F. and Fernández-Villagómez, G. (1997) Solid substrate anaerobic co-digestion of paper mill sludge, biosolids, and municipal solid waste. Water Sci. Technol. 35(2-3), 197-204.

Rajagopal, R., Masse, D.I. and Singh, G. (2013) A critical review on inhibition of anaerobic digestion process by excess ammonia. Bioresour. Technol. 143, 632641.

Richards, B.K., Cummings, R.J., White, T.E. and Jewell, W.J. (1991) Methods for kinetic analysis of methane fermentation in high solids biomass digesters. Biomass Bioenergy 1(2), 65-73.

Rodríguez, J., Lema, J.M., van Loosdrecht, M.C.M. and Kleerebezem, R. (2006) Variable stoichiometry with thermodynamic control in ADM1. Water Sci. Technol. 54(4), 101-110.

Rosén, C. and Jeppsson, U. (2006) Aspects on ADM1 implementation within the BSM2 framework., Division of Industrial Electrical Engineering and Automation, Faculty of Engineering, Lund University, Sweden.

van Veen, J.A. and Paul, E.A. (1979) Conversion of biovolume measurements of soil organisms, grown under various moisture tensions, to biomass and nutrient content. Appl. Environ. Microbiol. 37(4), 686-692.

Vanrolleghem, P., Van Daele, M. and Dochain, D. (1995) Practical identifiability of biokinetic model of activated sludge respiration. Water Res. 29(11), 2561-2570.

Vavilin, V.A. and Angelidaki, I. (2005) Anaerobic degradation of solid material: importance of initiation centers for methanogenesis, mixing intensity, and 2D distributed model. Biotechnol. Bioeng. 89(1), 113-122.

Vavilin, V.A., Fernandez, B., Palatsi, J. and Flotats, X. (2008) Hydrolysis kinetics in anaerobic degradation of particulate organic material: an overview. Waste Manage. 28(6), 939-951.

Vavilin, V.A., Lokshina, L.Y., Jokela, J.P. and Rintala, J.A. (2004) Modeling solid waste decomposition. Bioresour. Technol. 94(1), 69-81.

Vavilin, V.A., Rytov, S.V., Lokshina, L.Y., Pavlostathis, S.G. and Barlaz, M.A. (2003) Distributed model of solid waste anaerobic digestion: effects of leachate recirculation and $\mathrm{pH}$ adjustment. Biotechnol. Bioeng. 81(1), 66-73.

$\mathrm{Xu}, \mathrm{F}$., Li, Y. and Wang, Z.-W. (2015) Mathematical modeling of solid-state anaerobic digestion. Prog. Energy Combust. Sci. 51, 49-66.

Table 1: Biochemical kinetics used for model implementation verification and calibration.

Table 2: Influent and initial conditions used for model implementation verification and model calibration.

Table 3: Summary of steady-state results for model implementation verification.

Table 4: Main parameters modified for model calibration.

Figure 1: High-solids vs. 'wet' anaerobic digestion.

Figure 2: Schematic representation of the high-solids anaerobic digestion model implementation.

Figure 3: Hydraulic retention time and organic loading rate in model implementation verification: a) 'wet' anaerobic digestion (simulations $\mathrm{A}$ and $\mathrm{B}$ ); and b) high-solids anaerobic digestion (simulations $\mathrm{C}$ and $\mathrm{D}$ ). 
698 Figure 4: Batch mono-digestion of OFMSW at $15 \%$ total solids: a) accumulated 699 methane production and reactor mass content; b) volatile fatty acids; c) total and free 700 ammonia nitrogen; and d) total and volatile solids.

701

702 
1 Table 1: Biochemical kinetics used for model implementation verification and 2 calibration.

3

\begin{tabular}{|c|c|c|}
\hline \multirow{2}{*}{ Process } & \multicolumn{2}{|c|}{ Rate $\left(\rho_{j}, k_{\text {COD m }}^{-3} d^{-1}\right)$} \\
\hline & Model Verification & Model Calibration \\
\hline Disintegration & $\mathrm{k}_{\mathrm{dis}} * \mathrm{X}_{\mathrm{c}}$ & - \\
\hline $\begin{array}{l}\text { Hydrolysis of } \\
\text { Carbohydrates }\end{array}$ & $\mathrm{k}_{\mathrm{h}, \mathrm{ch}} * \mathrm{X}_{\mathrm{ch}}$ & $\mathrm{k}_{\mathrm{h}, \mathrm{ch}} * \mathrm{X}_{\mathrm{ch}}$ \\
\hline Hydrolysis of Proteins & $\mathrm{k}_{\mathrm{h}, \mathrm{pr}} * \mathrm{X}_{\mathrm{pr}}$ & $\mathrm{k}_{\mathrm{h}, \mathrm{pr}} * \mathrm{X}_{\mathrm{pr}}$ \\
\hline Hydrolysis of Lipids & $\mathrm{k}_{\mathrm{h}, \mathrm{li}} * \mathrm{X}_{\mathrm{li}}$ & $\mathrm{k}_{\mathrm{h}, \mathrm{li}} * \mathrm{X}_{\mathrm{li}}$ \\
\hline Sugars Uptake & $\mathrm{k}_{\mathrm{m}, \mathrm{su}} * \mathrm{~S}_{\mathrm{su}, \mathrm{App}} /\left(\mathrm{K}_{\mathrm{S}, \mathrm{Xsu}}+\mathrm{S}_{\mathrm{su}, \mathrm{App}}\right) * \mathrm{X}_{\mathrm{su}} * \mathrm{I}_{\mathrm{pH}} * \mathrm{I}_{\mathrm{in}}$ & $\mathrm{k}_{\mathrm{m}, \mathrm{su}} * \mathrm{~S}_{\mathrm{su}, \mathrm{App}} /\left(\mathrm{K}_{\mathrm{S}, \mathrm{Xsu}}+\mathrm{S}_{\mathrm{su}, \mathrm{App}}\right) * \mathrm{X}_{\mathrm{su}} * \mathrm{I}_{\mathrm{pH}} * \mathrm{I}_{\mathrm{in}}$ \\
\hline Aminoacids Uptake & $\mathrm{k}_{\mathrm{m}, \mathrm{aa}} * \mathrm{~S}_{\mathrm{aa}, \mathrm{App}} /\left(\mathrm{K}_{\mathrm{S}, \mathrm{Xaa}}+\mathrm{S}_{\mathrm{aa}, \mathrm{App}}\right) * \mathrm{X}_{\mathrm{aa}} * \mathrm{I}_{\mathrm{pH}} * \mathrm{I}_{\mathrm{in}}$ & $\mathrm{k}_{\mathrm{m}, \mathrm{aa}} * \mathrm{~S}_{\mathrm{aa}, \mathrm{App}} /\left(\mathrm{K}_{\mathrm{S}, \mathrm{Xaa}}+\mathrm{S}_{\mathrm{aa}, \mathrm{App}}\right) * \mathrm{X}_{\mathrm{aa}} * \mathrm{I}_{\mathrm{pH}} * \mathrm{I}_{\mathrm{in}}$ \\
\hline LCFA Uptake & $\mathrm{k}_{\mathrm{m}, \mathrm{fa}} * \mathrm{~S}_{\mathrm{fa}} /\left(\mathrm{K}_{\mathrm{S}, \mathrm{Xfa}}+\mathrm{S}_{\mathrm{fa}}\right) * \mathrm{X}_{\mathrm{fa}} * \mathrm{I}_{\mathrm{pH}} * \mathrm{I}_{\mathrm{in}} * \mathrm{I}_{\mathrm{h} 2}$ & $\mathrm{k}_{\mathrm{m}, \mathrm{fa}} * \mathrm{~S}_{\mathrm{fa}} /\left(\mathrm{K}_{\mathrm{S}, \mathrm{Xfa}}+\mathrm{S}_{\mathrm{fa}}\right) * \mathrm{X}_{\mathrm{fa}} * \mathrm{I}_{\mathrm{pH}} * \mathrm{I}_{\mathrm{in}} * \mathrm{I}_{\mathrm{h} 2}$ \\
\hline Valerate Uptake & 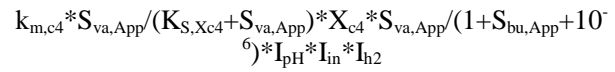 & 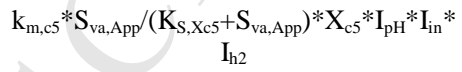 \\
\hline Butyrate Uptake & $\mathrm{k}_{\mathrm{m}, \mathrm{c}} * \mathrm{~S}_{\mathrm{bu}, \mathrm{App}} /\left(\mathrm{K}_{\mathrm{s}, \mathrm{Xc} 4}+{ }_{6}+\mathrm{S}_{\mathrm{bu}, \mathrm{App}}\right) * \mathrm{I}_{\mathrm{pH}} * \mathrm{I}_{\mathrm{in}} * \mathrm{I}_{\mathrm{in} 2} * \mathrm{~S}_{\mathrm{bu}, \mathrm{App}} /\left(1+\mathrm{S}_{\mathrm{bu}, \mathrm{App}}+10^{-}\right.$ & $\underset{\mathrm{k}_{\mathrm{m}, \mathrm{ct}} * \mathrm{~S}_{\mathrm{bu}, \mathrm{App}} /\left(\mathrm{K}_{\mathrm{s}, \mathrm{Xc} 4}+\mathrm{S}_{\mathrm{bu}, \mathrm{App}}\right) * \mathrm{X}_{\mathrm{c} 4} * \mathrm{I}_{\mathrm{pH}} * \mathrm{I}_{\mathrm{in}} * \mathrm{I}_{\mathrm{h} 2}}{*}$ \\
\hline Propionate Uptake & $\mathrm{k}_{\mathrm{m}, \mathrm{pro}} * \mathrm{~S}_{\mathrm{pro}, \mathrm{App}} /\left(\mathrm{K}_{\mathrm{S}, \mathrm{Xpro}}+\mathrm{S}_{\mathrm{pro}, \mathrm{App}}\right) * \mathrm{X}_{\mathrm{pro}} * \mathrm{I}$ & 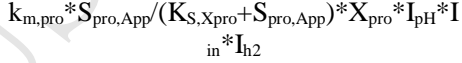 \\
\hline Acetate Uptake & $\mathrm{k}_{\mathrm{m}, \mathrm{ac}} * \mathrm{~s}$ & $\mathrm{k}_{\mathrm{m}, \mathrm{ac}}{ }^{*} \mathrm{~S}_{\mathrm{ac}, \mathrm{App}} /\left(\mathrm{K}_{\mathrm{S}, \mathrm{Xac}}+\mathrm{S}_{\mathrm{ac}, \mathrm{App}}\right) * \mathrm{X}_{\mathrm{ac}} * \mathrm{I}_{\mathrm{pH}} * \mathrm{I}_{\mathrm{in}} * \mathrm{I}$ \\
\hline Hydrogen Uptake & $\mathrm{k}_{\mathrm{m}, \mathrm{h} 2} * \mathrm{~S}_{\mathrm{h} 2, \mathrm{App}} /\left(\mathrm{K}_{\mathrm{S}, \mathrm{Xh} 2}+\mathrm{S}_{\mathrm{h} 2, \mathrm{App}}\right.$ & $\mathrm{k}_{\mathrm{m}, \mathrm{h} 2} * \mathrm{~S}_{\mathrm{h} 2, \mathrm{App}} /\left(\mathrm{K}_{\mathrm{S}, \mathrm{Xh} 2}+\mathrm{S}_{\mathrm{h} 2, \mathrm{App}}\right) * \mathrm{X}_{\mathrm{h} 2} * \mathrm{I}_{\mathrm{pH}} * \mathrm{I}_{\mathrm{in}}$ \\
\hline Sugar Degraders Decay & $\mathrm{k}_{\mathrm{d}} * \mathrm{X}_{\mathrm{su}}$ & $\mathrm{k}_{\mathrm{d}} * \mathrm{X}_{\mathrm{su}}$ \\
\hline $\begin{array}{l}\text { Aminoacids Degraders } \\
\text { Decay }\end{array}$ & $\mathrm{k}_{\mathrm{d}} * \mathrm{X}_{\mathrm{aa}}$ & $\mathrm{k}_{\mathrm{d}} * \mathrm{X}_{\mathrm{aa}}$ \\
\hline LCFA Degraders Decay & $\mathrm{k}_{\mathrm{d}} * \mathrm{X}_{\mathrm{fa}}$ & $\mathrm{k}_{\mathrm{d}} * \mathrm{X}_{\mathrm{fa}}$ \\
\hline Valerate Degraders Decay & - & $\mathrm{k}_{\mathrm{d}} * \mathrm{X}_{\mathrm{c} 5}$ \\
\hline Butyrate Degraders Decay & $\mathrm{k}_{\mathrm{d}} * \mathrm{X}_{\mathrm{c} 4}$ & $\mathrm{k}_{\mathrm{d}} * \mathrm{X}_{\mathrm{c} 4}$ \\
\hline $\begin{array}{l}\text { Propionate Degraders } \\
\text { Decay }\end{array}$ & & $\mathrm{k}_{\mathrm{d}} * \mathrm{X}_{\mathrm{pro}}$ \\
\hline Acetate Degraders Decay & & $\mathrm{k}_{\mathrm{d}} * \mathrm{X}_{\mathrm{ac}}$ \\
\hline $\begin{array}{l}\text { Hydrogen Degraders } \\
\text { Decay }\end{array}$ & $\mathrm{k}_{\mathrm{d}} * \mathrm{X}_{\mathrm{h} 2}$ & $\mathrm{k}_{\mathrm{d}} * \mathrm{X}_{\mathrm{h} 2}$ \\
\hline
\end{tabular}

4

$$
\text { with } \begin{aligned}
\mathrm{I}_{\mathrm{in}} & =\mathrm{S}_{\mathrm{in}, \mathrm{App}} /\left(\mathrm{K}_{\mathrm{S}, \mathrm{Sin}}+\mathrm{S}_{\mathrm{in}, \mathrm{App}}\right) \\
\mathrm{I}_{\mathrm{h} 2} & =\mathrm{K}_{\mathrm{i}, \mathrm{Sh} 2} /\left(\mathrm{K}_{\mathrm{i}, \mathrm{Sh} 2}+\mathrm{S}_{\mathrm{h} 2, \mathrm{App}}\right) \\
\mathrm{I}_{\mathrm{pH}} & =\mathrm{K}_{\mathrm{pH}} \wedge \mathrm{N}_{\mathrm{pH}} /\left(\mathrm{K}_{\mathrm{pH}} \wedge N_{\mathrm{pH}}+\mathrm{S}_{\mathrm{h}+} \wedge \mathrm{N}_{\mathrm{pH}}\right) \\
\mathrm{I}_{\mathrm{nh} 3} & =\mathrm{K}_{\mathrm{i}, \mathrm{Snh} 3} /\left(\mathrm{K}_{\mathrm{i}, \mathrm{Snh} 3}+\mathrm{S}_{\mathrm{nh} 3, \mathrm{App}}\right)
\end{aligned}
$$


1 Table 2: Influent and initial conditions used for model implementation verification and 2 model calibration.

3

\begin{tabular}{|c|c|c|c|c|c|}
\hline \multirow{2}{*}{ Name } & \multicolumn{3}{|c|}{ Model Verification } & \multirow{2}{*}{$\begin{array}{c}\text { Model } \\
\text { Calibration }\end{array}$} & \multirow[b]{2}{*}{ Units } \\
\hline & Simulation A & Simulation B & $\begin{array}{c}\text { Simulations } \\
\text { C \& D }\end{array}$ & & \\
\hline $\mathrm{S}_{\mathrm{su}}$ & 0.010 & 0.010 & 0.010 & 13.557 & $\mathrm{~kg} \mathrm{COD} \mathrm{m}^{-3}$ \\
\hline $\mathrm{S}_{\mathrm{aa}}$ & 0.001 & 0.001 & 0.001 & 2.207 & $\mathrm{~kg} \mathrm{COD} \mathrm{m}^{-3}$ \\
\hline $\mathrm{S}_{\mathrm{fa}}$ & 0.001 & 0.001 & 0.001 & 1.393 & $\mathrm{~kg} \mathrm{COD} \mathrm{m}^{-3}$ \\
\hline$S_{v a}$ & 0.001 & 0.001 & 0.001 & 0.734 & $\mathrm{~kg} \mathrm{COD} \mathrm{m}^{-3}$ \\
\hline $\mathrm{S}_{\mathrm{bu}}$ & 0.001 & 0.001 & 0.001 & 0.500 & $\mathrm{~kg} \mathrm{COD} \mathrm{m}^{-3}$ \\
\hline $\mathrm{S}_{\mathrm{pro}}$ & 0.001 & 0.001 & 0.001 & 2.059 & $\mathrm{~kg} \mathrm{COD} \mathrm{m}^{-3}$ \\
\hline $\mathrm{S}_{\mathrm{ac}}$ & 0.001 & 0.001 & 0.001 & 0.103 & $\mathrm{~kg} \mathrm{COD} \mathrm{m}^{-3}$ \\
\hline $\mathrm{S}_{\mathrm{h} 2}$ & $1.000 \mathrm{E}-08$ & $1.000 \mathrm{E}-08$ & $1.000 \mathrm{E}-08$ & $1.000 \mathrm{E}-08$ & $\mathrm{~kg} \mathrm{COD} \mathrm{m}^{-3}$ \\
\hline $\mathrm{S}_{\mathrm{ch} 4}$ & $1.000 \mathrm{E}-08$ & $1.000 \mathrm{E}-08$ & $1.000 \mathrm{E}-08$ & $1.000 \mathrm{E}-08$ & $\mathrm{~kg} \mathrm{COD} \mathrm{m}^{-3}$ \\
\hline$S_{i c}$ & 0.040 & 0.040 & 0.040 & 0.029 & $\mathrm{kmol} \mathrm{C} \mathrm{m}^{-3}$ \\
\hline$S_{\text {in }}$ & 0.010 & 0.010 & 0.010 & 0.186 & $\mathrm{kmol} \mathrm{N} \mathrm{m}^{-3}$ \\
\hline $\mathrm{S}_{\mathrm{i}}$ & 0.020 & 0.020 & 0.020 & 0.000 & $\mathrm{~kg} \mathrm{COD} \mathrm{m}^{-3}$ \\
\hline $\mathrm{S}_{\mathrm{i}, \mathrm{subs}}$ & - & - & 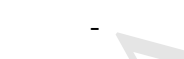 & 32.227 & $\mathrm{kgCOD} \mathrm{m}^{-3}$ \\
\hline$X_{c}$ & 2.000 & 2.000 & 2.000 & - & $\mathrm{kg} \mathrm{COD} \mathrm{m}^{-3}$ \\
\hline $\mathrm{X}_{\mathrm{ch}}$ & 5.000 & 5.000 & 120.000 & 40.671 & $\mathrm{~kg} \mathrm{COD} \mathrm{m}^{-3}$ \\
\hline $\mathrm{X}_{\mathrm{pr}}$ & 20.000 & 20.000 & 20.000 & 30.902 & $\mathrm{~kg} \mathrm{COD} \mathrm{m}^{-3}$ \\
\hline $\mathrm{X}_{\mathrm{g}}$ & 5.000 & 5.000 & 5.000 & 12.534 & $\mathrm{~kg} \mathrm{COD} \mathrm{m}^{-3}$ \\
\hline $\mathrm{X}_{\mathrm{su}}$ & 0.010 & 0.010 & 0.010 & 0.050 & $\mathrm{~kg} \mathrm{COD} \mathrm{m}^{-3}$ \\
\hline $\mathrm{X}_{\mathrm{aa}}$ & 0.010 & 0.010 & 0.010 & 0.050 & $\mathrm{~kg} \mathrm{COD} \mathrm{m}^{-3}$ \\
\hline $\mathrm{X}_{\mathrm{fa}}$ & 0.010 & 0.010 & 0.010 & 0.001 & $\mathrm{~kg} \mathrm{COD} \mathrm{m}^{-3}$ \\
\hline$X_{c 5}$ & - & - & - & 0.010 & $\mathrm{kgCOD} \mathrm{m}^{-3}$ \\
\hline$X_{c 4}$ & 0.010 & 0.010 & 0.010 & 0.002 & $\mathrm{~kg} \mathrm{COD} \mathrm{m}^{-3}$ \\
\hline$X_{\text {pro }}$ & 0.010 & 0.010 & 0.010 & 0.005 & $\mathrm{~kg} \mathrm{COD} \mathrm{m}^{-3}$ \\
\hline $\mathrm{X}_{\mathrm{ac}}$ & 0.010 & 0.010 & 0.010 & 0.003 & $\mathrm{~kg} \mathrm{COD} \mathrm{m}^{-3}$ \\
\hline $\mathrm{X}_{\mathrm{h} 2}$ & 0.010 & 0.010 & 0.010 & 0.070 & $\mathrm{~kg} \mathrm{COD} \mathrm{m}^{-3}$ \\
\hline $\mathrm{X}_{\mathrm{i}}$ & 25.000 & 25.000 & 250.000 & 0.000 & $\mathrm{~kg} \mathrm{COD} \mathrm{m}^{-3}$ \\
\hline $\mathrm{X}_{\mathrm{i}, \mathrm{subs}}$ & - & - & - & 80.567 & $\mathrm{kgCOD} \mathrm{m}^{-3}$ \\
\hline$S_{\text {cat }}$ & 0.040 & 0.040 & 0.040 & 0.100 & kmoleq $\mathrm{m}^{-3}$ \\
\hline $\mathrm{S}_{\mathrm{an}}$ & 0.020 & 0.020 & 0.020 & 0.051 & kmoleq $\mathrm{m}^{-3}$ \\
\hline$\rho_{\text {Global }}$ & - & 1000.000 & 1100.000 & 1077.633 & $\mathrm{~kg} \mathrm{~m}^{-3}$ \\
\hline TS & - & 4.500 & 25.000 & 15.502 & $\%$ \\
\hline VS & - & 3.500 & 23.000 & 12.942 & $\%$ \\
\hline
\end{tabular}


1 Table 3: Summary of steady-state results for model implementation verification.

\begin{tabular}{|c|c|c|c|c|c|c|}
\hline \multirow[b]{2}{*}{$\begin{array}{c}\text { Variab } \\
\text { le }\end{array}$} & \multicolumn{2}{|c|}{ ADM1 Implementation } & \multicolumn{3}{|c|}{ HS-AD Model Implementation } & \multirow[b]{2}{*}{ Units } \\
\hline & $\begin{array}{c}\text { Rosen \& Jeppsson } \\
\text { (2006) }\end{array}$ & $\begin{array}{l}\text { 'Wet' } \\
\text { AD }\end{array}$ & $\begin{array}{c}\text { 'Wet' AD Const. } \\
\text { Effluent** }\end{array}$ & $\begin{array}{c}\text { HS-AD Const. } \\
\text { Effluent** }\end{array}$ & $\begin{array}{c}\text { HS-AD Variable } \\
\text { Effluent }\end{array}$ & \\
\hline $\mathrm{S}_{\mathrm{su}}$ & 0.01195 & 0.01195 & 0.01269 & 0.01692 & 0.01000 & $\mathrm{~kg} \mathrm{COD} \mathrm{m}^{-3}$ \\
\hline $\mathrm{S}_{\mathrm{ac}}$ & 0.19763 & 0.19721 & 0.27484 & 0.16339 & 0.05707 & $\mathrm{~kg} \mathrm{COD} \mathrm{m}^{-3}$ \\
\hline$S_{\text {ic }}$ & 0.15268 & 0.15270 & 0.15232 & 0.11377 & 0.11028 & kmole $\mathrm{C} \mathrm{m}^{-3}$ \\
\hline $\mathrm{S}_{\text {in }}$ & 0.13023 & 0.13023 & 0.13129 & 0.08451 & 0.07803 & $\underset{3}{\text { kmole }} \mathrm{N} \mathrm{m}^{-}$ \\
\hline$X_{\mathrm{ch}}$ & 0.02795 & 0.02795 & 0.03183 & 60.73693 & 41.21685 & $\mathrm{~kg} \mathrm{COD} \mathrm{m}^{-3}$ \\
\hline $\mathrm{X}_{\mathrm{su}}$ & 0.42017 & 0.42017 & 0.43628 & 5.38786 & 6.15898 & $\mathrm{~kg} \mathrm{COD} \mathrm{m}^{-3}$ \\
\hline $\mathrm{X}_{\mathrm{ac}}$ & 0.76056 & 0.76058 & 0.78837 & 2.35994 & 2.52894 & $\mathrm{~kg} \mathrm{COD} \mathrm{m}^{-3}$ \\
\hline $\mathrm{Q}_{\text {Effluent }}$ & 170 & 170 & 170 & 170 & 160 & $\mathrm{~m}^{3} \mathrm{~d}^{-1}$ \\
\hline $\mathrm{pH}$ & 7.47 & 7.46 & 7.48 & 7.20 & 7.16 & $\mathrm{~m}^{3} \mathrm{~d}^{-1}$ \\
\hline $\mathrm{S}_{\mathrm{co} 2}$ & 0.0099 & 0.0099 & 0.0096 & 0.0128 & 0.0134 & $\mathrm{kmol} \mathrm{C} \mathrm{m}^{-3}$ \\
\hline $\mathrm{S}_{\mathrm{nh} 3}$ & 0.0041 & 0.0041 & 0.0042 & 0.0015 & 0.0012 & $\mathrm{kmol} \mathrm{N} \mathrm{m}^{-3}$ \\
\hline $\mathrm{P}_{\mathrm{T}}$ & 1.069 & 1.069 & 1.069 & 1.180 & 1.220 & bar \\
\hline $\mathrm{Q}_{\mathrm{g}}$ & 2956 & 2956 & 2939 & 9752 & 12472 & $\mathrm{Nm}^{3} \mathrm{~d}^{-1}$ \\
\hline$\% \mathrm{CH}_{4}$ & $61^{*}$ & 60.9 & 60.8 & 50.6 & 49.9 & $\%$ \\
\hline$\% \mathrm{CO}_{2}$ & $34^{*}$ & 33.9 & 34.0 & 44.7 & 45.5 & $\%$ \\
\hline $\mathrm{V}_{\text {Global }}$ & 3400 & 3400 & 2967 & 1717 & 3400 & $\mathrm{~m}^{3}$ \\
\hline$\rho_{\text {Globalo }}$ & - & 1000 & 1000 & 1100 & 1100 & $\mathrm{~kg} \mathrm{~m}^{-3}$ \\
\hline$\rho_{\text {Global }}$ & - & 1000 & 995 & 1082 & 1077 & $\mathrm{~kg} \mathrm{~m}^{-3}$ \\
\hline HRT & $20 *$ & 20 & 20 & 20 & 20 & d \\
\hline $\mathrm{HRT}_{\text {real }}$ & - & 20 & 17 & 10 & 20 & $\mathrm{~d}$ \\
\hline OLR & - & 2.85 & 2.85 & 19.85 & 19.85 & $\underset{\mathrm{d}^{-1}}{\mathrm{~kg} \mathrm{COD} \mathrm{m}}$ \\
\hline $\mathrm{OLR}_{\text {real }}$ & - & 2.85 & 3.27 & 39.32 & 19.86 & $\underset{\mathrm{d}^{-1}}{\mathrm{kgCOD} \mathrm{m}^{-3}}$ \\
\hline $\mathrm{TS}_{0}$ & $4.5^{*}$ & - & 4.5 & 25.0 & 25.0 & $\%$ \\
\hline TS & - & - & 2.9 & 20.4 & 19.0 & $\%$ \\
\hline $\mathrm{TS}_{\text {Recalc }}$ & - & - & 1.9 & 19.8 & 18.5 & $\%$ \\
\hline $\mathrm{VS}_{0}$ & - & - & 3.5 & 23.0 & 23.0 & $\%$ \\
\hline VS & - & - & 1.8 & 18.2 & 16.9 & $\%$ \\
\hline $\mathrm{VS}_{\text {Recalc }}$ & - & - & 0.9 & 17.6 & 16.3 & $\%$ \\
\hline
\end{tabular}


1 Table 4: Main parameters modified for model calibration.

\begin{tabular}{cccc}
\hline Parameter & ADM1 & This Study & Units \\
\hline $\mathrm{k}_{\mathrm{h}, \mathrm{ch}}$ & 10 & 0.05 & $\mathrm{~d}^{-1}$ \\
$\mathrm{k}_{\mathrm{h}, \mathrm{pr}}$ & 10 & 0.05 & $\mathrm{~d}^{-1}$ \\
$\mathrm{k}_{\mathrm{h}, \mathrm{li}}$ & 10 & 0.07 & $\mathrm{~d}^{-1}$ \\
$\mathrm{k}_{\mathrm{m}, \mathrm{su}}$ & 70 & 35 & $\mathrm{~d}^{-1}$ \\
$\mathrm{k}_{\mathrm{m}, \mathrm{fa}}$ & 10 & 4 & $\mathrm{~d}^{-1}$ \\
$\mathrm{k}_{\mathrm{m}, \mathrm{c} 5}$ & 30 & 1 & $\mathrm{~d}^{-1}$ \\
$\mathrm{k}_{\mathrm{m}, \mathrm{c} 4}$ & 30 & 6 & $\mathrm{~d}^{-1}$ \\
$\mathrm{k}_{\mathrm{m}, \mathrm{pro}}$ & 20 & 1 & $\mathrm{~d}^{-1}$ \\
$\mathrm{pH}_{\mathrm{LL}, \mathrm{ac}}$ & 6 & 5.8 & \\
$\mathrm{pH}_{\mathrm{UL}, \mathrm{ac}}$ & 7 & 6.8 & \\
$\mathrm{f}_{\mathrm{bu}, \mathrm{su}}$ & 0.13 & 0.37 & \\
$\mathrm{f}_{\mathrm{pro}, \mathrm{su}}$ & 0.27 & 0.11 & \\
$\mathrm{f}_{\mathrm{a}, \mathrm{su}}$ & 0.41 & 0.40 & \\
$\mathrm{f}_{\mathrm{h} 2, \mathrm{su}}$ & 0.19 & 0.12 & \\
$\mathrm{~N}_{\mathrm{i}, \mathrm{subs}}$ & - & 0.001 & $\mathrm{kmol} \mathrm{N} \mathrm{m^{-3 }}$ \\
\hline
\end{tabular}

2

3 


\section{'Wet' Anaerobic Digestion}

$$
\begin{gathered}
\mathrm{Q}_{0}=\mathrm{Q}_{\mathrm{e}}=\mathrm{Q} \\
\mathrm{V}_{\text {Global }}=\text { const. } \\
V_{\text {Global }} \frac{d \rho}{d t}=Q\left(\rho_{0}-\rho\right)-\sum r_{i}
\end{gathered}
$$

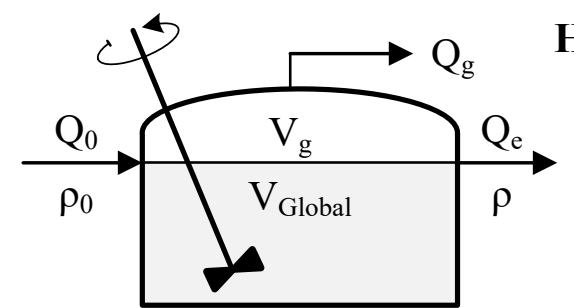

High-Solids Anaerobic Digestion

$$
\begin{gathered}
\mathrm{Q}_{0} \neq \mathrm{Q}_{\mathrm{e}} \\
\mathrm{V}_{\text {Global }} \neq \text { const. } \\
\frac{d\left(\rho V_{\text {Global }}\right)}{d t}=\rho_{0} Q_{0}-\rho Q_{e}-\sum r_{i}
\end{gathered}
$$

Figure 1: High-solids vs. 'wet' anaerobic digestion. 


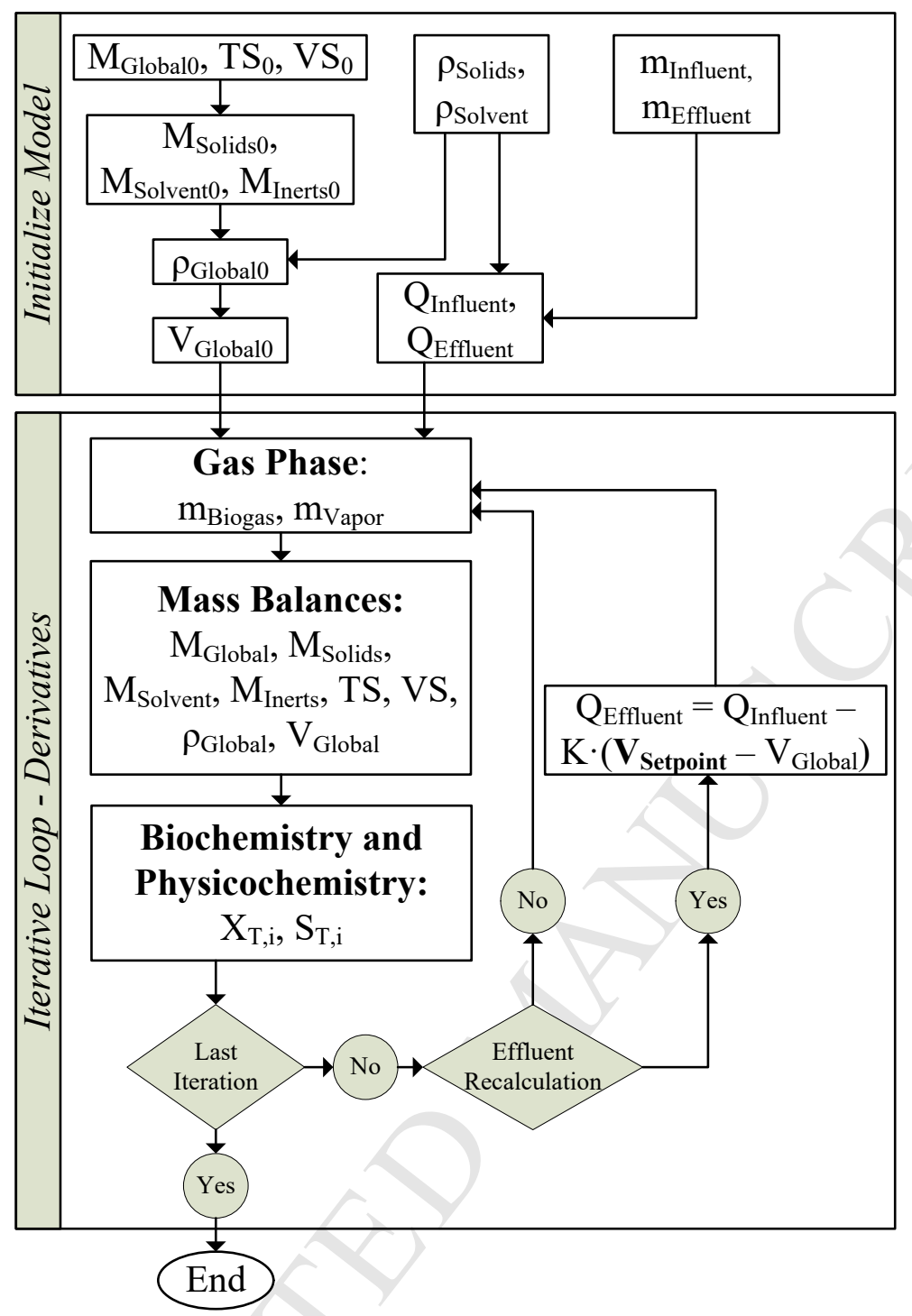

Figure 2: Schematic representation of the high-solids anaerobic digestion model implementation. 

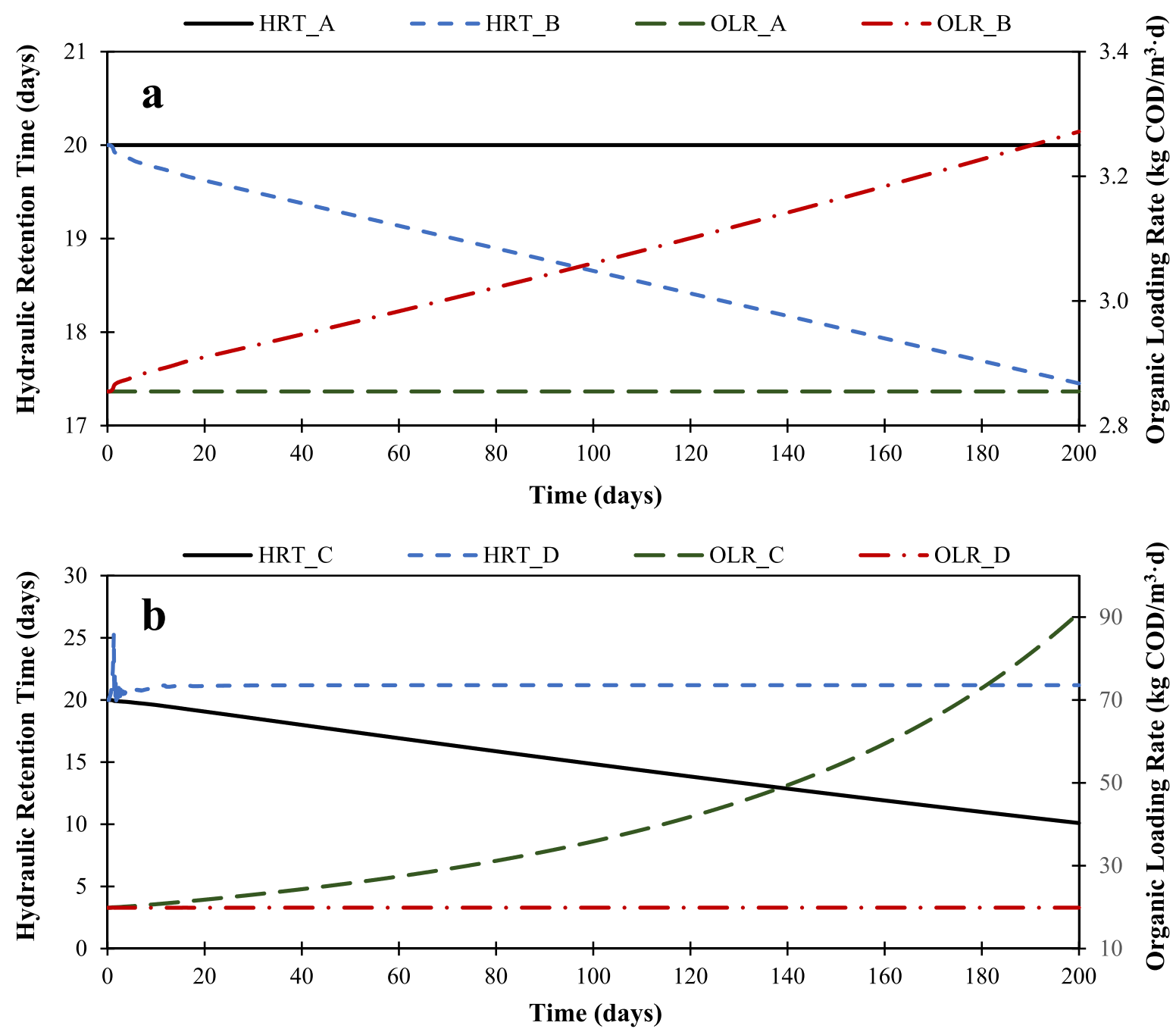

Figure 3: Hydraulic retention time and organic loading rate in model implementation verification: a) 'wet' anaerobic digestion (simulations A and B); and b) high-solids anaerobic digestion (simulations $\mathrm{C}$ and $\mathrm{D}$ ). 

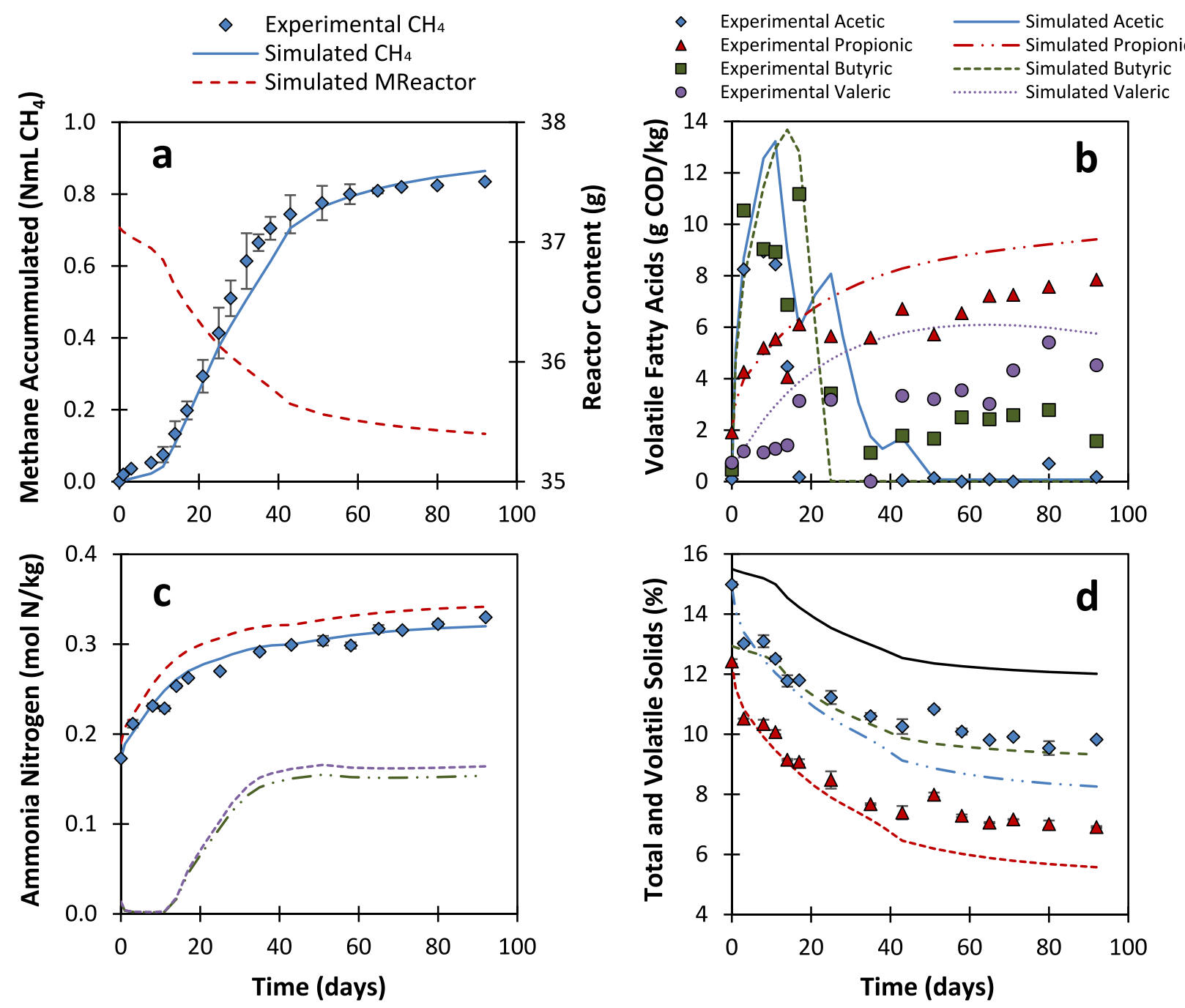

$\diamond \quad$ Experimental TAN Simulated TAN

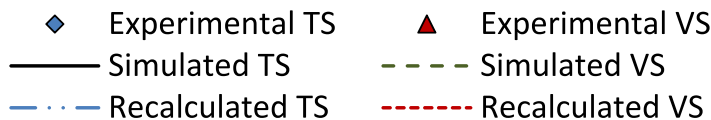

Figure 4: Batch mono-digestion of OFMSW at $15 \%$ total solids: a) accumulated methane production and reactor mass content; b) volatile fatty acids; c) total and free ammonia nitrogen; and d) total and volatile solids. 


\section{Highlights}

- A novel HS-AD model based on ADM1 was developed for homogenized reactors.

- Reactor mass/volume and total solids dynamics in HS-AD were simulated.

- The model considers the TS concentration effect on soluble species in HS-AD.

- The model simulated adequately VFA and TAN of HS-AD using OFMSW as substrate. 